\title{
LATE QUATERNARY HISTORY OF THE ACCUMULATION \\ PLAIN NORTH OF THE CHEKANOVSKY RIDGE (LENA DELTA, RUSSIA): A MULTIDISCIPLINARY APPROACH ${ }^{1}$
}

\author{
L. Schirrmeister, G. Grosse, G. Schwamborn, A. A. Andreev, and H. Meyer \\ Alfred Wegener Institute for Polar and Marine Research, \\ Research Unit Potsdam, Telegrafenberg, 14473 Potsdam, Germany
}

\author{
V. V. Kunitsky \\ Permafrost Institute, \\ Siberian Branch Russian Academy of Science Yakutsk, Russia
}

T. V. Kuznetsova

Faculty of Geology, Moscow State University, Vorobievy Gory, Moscow, Russia

M. V. Dorozhkina and E. Y. Pavlova

Arctic and Antarctic Research Institute, Bering Street, St. Petersburg, Russia

A. A. Bobrov

Faculty of Soil Science Moscow State University, Vorobievy Gory, Moscow, Russia

D. Oezen

Leibniz Institute for Applied Geoscience (GGA), Hanover, Germany

Abstract: Permafrost deposits were studied along the Olenyeksky and the Arinsky distributaries in the western Lena delta using a multidisciplinary approach that included sedimentological, mineralogical, stable-isotope, and paleoecological analyses in order to reconstruct the Late Quaternary landscape and environmental history of this Northeast

${ }^{1}$ The paper is based on activities, expeditions, and analyses financed by the German Ministries for Science and Technology (BMBF), the Russian Ministry of Science, and the Russian Foundation for Basic Research (project No. 98-05-65506) under the auspices of the German-Russian cooperative project "System Laptev Sea 2000.” The authors thank L. D. Sulerzhitsky for the ${ }^{14} \mathrm{C}$ dating of bones, and Leibniz-Labor for Age Determination and Isotope Studies (Christian Albrecht University, Kiel) for AMS and conventional ${ }^{14} \mathrm{C}$ dating. These results would not have been obtained without the help of Russian colleagues from the Lena Delta Reserve, as well as the Tiksi Hydrobase during field work. We also thank the laboratory team from the Alfred Wegener Institute in Potsdam for sample preparation and a great number of chemical analyses. We also thank Helga Henschel and Paul Jasinski for a critical reading and help with improving the English. 
Siberian region. The studied sequence consists of two main units that differed in age, lithology, geocryology, and paleoecological bio-indicators. The lower sandy unit is interpreted as a shallow-water point-bar deposit of a paleo-Lena River. The upper unit contains the facially different Ice Complex deposits along with large ice wedges and numerous paleosols consisting of clastic material originating from the neighboring Chekanovsky Ridge to the south. These Ice Complex deposits are typical Late Pleistocene sediments in Siberia and are widely distributed in the coastal plains in Northeast Siberia.

\section{INTRODUCTION}

During the last decades, the Russian Arctic has been the focus of numerous studies of Quaternary paleoenvironments and paleoclimate. The limits of the Eurasian Ice sheet in the European and West Siberian Russian Arctic during the Weichselian was studied within the framework of the QUEEN project (Quaternary Environment of the Eurasian North) using terrestrial and marine records (Mangerud et al., 1999, 2002; Svendsen et al., 1999). Polyak analyzed numerous marine boreholes to study the lateand postglacial marine environment in these regions (Polyak and Solheim, 1994; Polyak and Mikhailov, 1996; Polyak et al., 2000). Paleoenvironmental records from Beringia (the area from Alaska to Northeast Siberia) were analyzed and summarized by Elias and Brigham-Grette (2001). The Laptev Sea region is an important link between European and West Siberian Russian Arctic and Beringia. While paleoenvironmental studies were carried out in this region within the scope of the Russian-German scientific cooperation "System Laptev Sea" (Kassens et al., 1999; Rachold, 2002), this study focuses on the special case of permafrost sequences in the western part of the Lena River delta. The data and results add a piece to the mosaic of the reconstruction of the climatically sensitive Late Quaternary Arctic environment.

A broad foreland plain lies north of the Chekanovsky Ridge. Near the mountains, the absolute elevation of the watershed reaches up to $100 \mathrm{~m}$ and decreases to $20 \mathrm{~m}$ farther north. This gently inclined plain is cut into numerous separate fragments by the Bulukursky, Olenyeksky, Arynsky, and other branches (distributaries) of the lower Lena River, as well as the small rivers and brooks that drain the slopes of the Chekanovsky Ridge. Several islands in the western Lena Delta, including Ebe-BasynSise, Khardang-Sise, Dzhangylakh-Sise, and Kurungnakh-Sise (Fig. 1) are part of these fragments.

Complex Quaternary deposits characterize the surface of these islands. The composition and structure of these sediments have been described in a number of publications (Sachs and Strelkov, 1960; Gusev, 1961; Lungersgauzen, 1961; Grigoriev, 1966; Ivanov, 1972; Kolpakov, 1983; Galabala, 1987; Kunitsky, 1989). The origin of these deposits is disputed, particularly the upper layer that contains the so-called "Ice Complex", a specific cryolithologenic formation comprised of large ice wedges and icerich sediment. The origin of the Ice Complex is of special interest; as these deposits cover large areas of northeast Siberia. While these Late Quaternary permafrost sediments are excellent paleoenvironmental archives, because of numerous, wellpreserved fossil records, they have not been sufficiently studied. The deposits have been variously interpreted as being: fluviolacustrine (Sachs and Strelkov, 1960; Gusev, 1961; Lungersgauzen, 1961), alluvial and fluviolacustrine (Ivanov, 1972), cryogenic-eolian (Tomirdiaro, 1980, 1982; Tomirdiaro and Chernen'kiy, 1987) or 


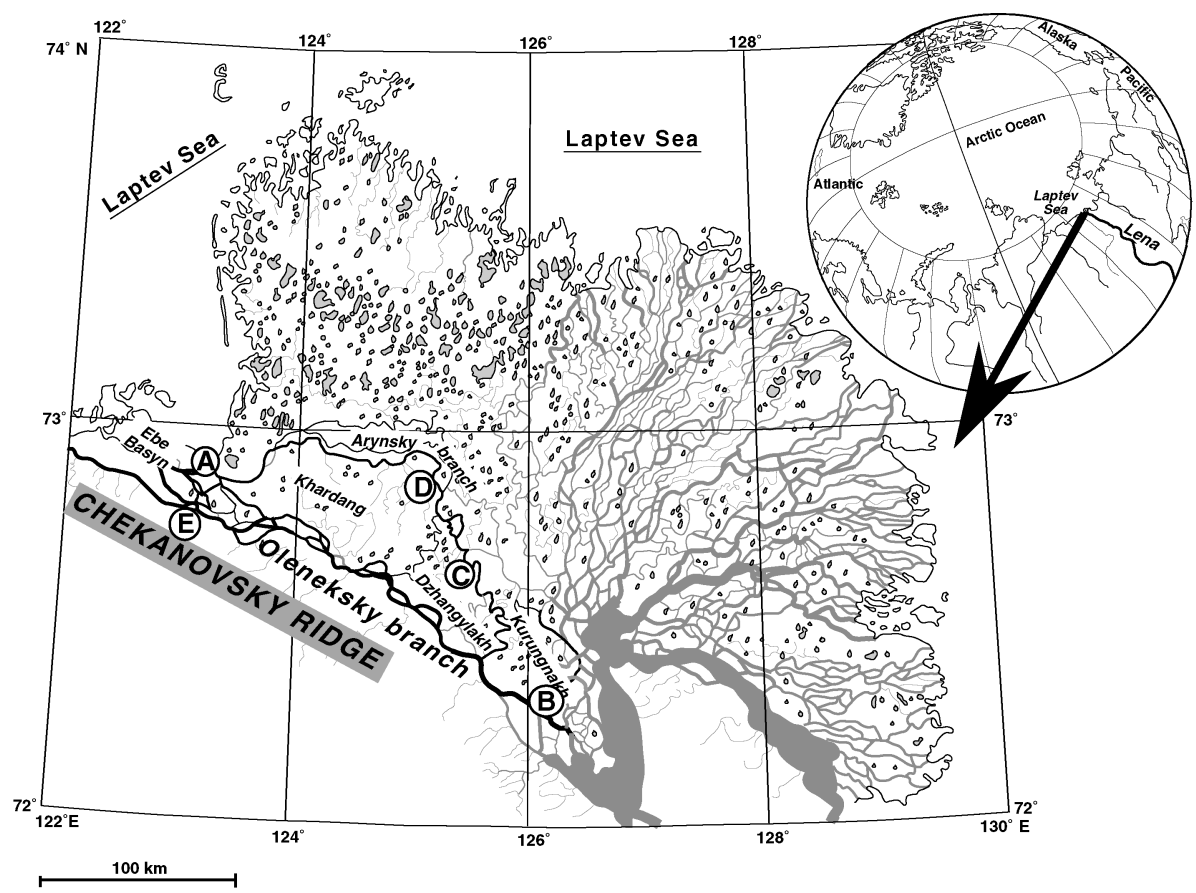

Fig. 1. Map of the Lena Delta with study sites. Legend: $A=$ Nagym; $B=$ Buor Khaya; $C=$ Sasyr; D = Mys Khaya; E = Chekanovsky Ridge.

eolian (Kolpakov, 1983). Kunitsky (1989) suggested that Ice Complex deposits represent a nival variant of terrestrial slope deposits, which were the original source of these deposits formed around snowfields and firn fields (so-called "extranivities"). This idea was based on lithological studies in the lower Lena River and neighboring regions (Kunitsky et al., 2002). New data on the composition and structure of Quaternary deposits from the mouth of the Lena River were obtained in the frame of the Russian-German cooperative scientific project "System Laptev Sea 2000" from 1998 to 2000 (Rachold and Grigoriev, 1999, 2000, 2001; Schwamborn et al., 1999).

The objective of this paper is to depict the typical lithological, geocryological, and paleoenvironmental features of the Quaternary in the Lena River delta deposits, using the results of own field studies, age determinations, sedimentological data, stable isotopes, and paleoecological bioindicators (pollen and rhizopods). The results are of great importance for understanding the sedimentation processes involved in the formation of the Lena River Delta at the northern margin of the Siberian mainland during the Late Pleistocene. Four locations in the western Lena Delta were studied during the Russian-German expeditions "Lena Delta 2000." This paper includes field records and new age determinations for the study sites and summarizes the study area data. Further sedimentological and geochemical analyses were carried out with samples from two representative sites, where paleoecological bioindicators were also studied at one of the sites. The results of this study will help in understanding the evolution of the region's landscape and its connection with nival processes in the nearby Chekanovsky Ridge. 


\section{GEOLOGICAL AND GEOMORPHOLOGICAL CHARACTERISTICS OF THE STUDY AREA}

The $200 \mathrm{~km}$ long Olenyeksky distributary is the only major western outlet of the Lena Delta. The Chekanovsky Ridge borders this branch on the south, whereas the 30-40 m high third terrace of the Lena Delta is situated north of the ridge (Fig. 1). The Chekanovsky Ridge is a system of narrow asymmetrical anticlines and broad trough-like synclines (Mikulenko, 1996). This system consists generally of a sequence of overthrusted imbricate synclines. The tectonic dislocation continues to the north below the Lena Delta as a system of small grabens and horsts (Mikulenko, 1996). Quaternary tectonic activities may be responsible for the dissection of the area into several geomorphological and geological elements (Are and Reimnitz, 2000).

Two sediment suites characterize the geology of the Olenyeksky distributary. The lower, Bulugursky Suite is described as alluvial-eolian sandy deposits with gravel (Lungersgauzen, 1961). The upper, peaty, ice-rich Kobakh Suite (ibid.) discordantly overlies the Bulugursky Suite. According to Galabala (1987) the deposits including ice wedges are divided into four suites: the alluvial Muorinsky Suite $\left(\mathrm{Q}_{\mathrm{II}}{ }^{1}-\mathrm{Q}_{\mathrm{III}}{ }^{1}\right)$; the sandy, alluvial Turansky Suite $\left(\mathrm{Q}_{\mathrm{III}}{ }^{2}\right)$; the alluvial, ice wedge-rich Arynsky Suite $\left(\mathrm{Q}_{\mathrm{III}}{ }^{3}\right)$; and the overlying heterogeneous Khardangsky Suite $\left(\mathrm{Q}_{\mathrm{III}}{ }^{3-4}\right)$. The upper layers of the Khardangsky Suite are comprised of fluvial and delta-floodplain deposits.

On the northern bank of the Olenyeksky distributary, 30 to $40 \mathrm{~m}$ high cliffs alternate with Holocene thermokarst depressions (alasy) with gentle slopes. ${ }^{2}$ Several small thermoerosional valleys cut the northern side of the Olenyeksky branch and a few single pingos have been observed. Numerous peat-covered, sandy islands of the modern floodplain and the first terrace above the floodplain are situated along the Olenyeksky branch (Pavlova and Dorozhkina, 2000).

\section{FIELD AND LABORATORY INVESTIGATIONS}

Stratigraphy, sediment structures, and cryostructures of permafrost deposits from four sections located on the steep banks of the Olenyeksky and Arynsky distributaries in the western Lena Delta (Fig. 1) were studied during the three RussianGerman expeditions "Lena Delta 1998," "Lena Delta 1999," and "Lena Delta 2000" (Schwamborn et al., 1999; Doroshkina and Pavlova, 2000; Schirrmeister et al., 2001). Several subprofiles from cliff outcrops were analyzed for geocryology, sedimentology, and paleo-bioindicators. The height relations between these sites were measured by tape and therefore cannot be considered as absolute altitudes, but as height above the river water level.

Most of the age determinations were performed using radiocarbon Accelerator Mass Spectrometry (AMS) at the Leibniz Laboratory for Radiometric Dating and Stable Isotope Research, Kiel University. The Leibniz Laboratory reduces the background inherent to the spectrometer, which results in low background count rates of the detector, equivalent to an apparent age of $75 \mathrm{ka}$ (gated background) (Nadeau et al.,

${ }^{2}$ Alasy are flat, circular depressions (often filled by lakes) with meadow or meadow-steppe vegetation. They are produced in areas of permafrost by the thawing of ground ice, which results in the subsidence of overlying materials- $-E d$., $P G$. 
1997). Details of the Leibniz Laboratory AMS procedures are given in Nadeau et al. (1997, 1998). The recently obtained Infrared Optical Stimulated Luminescence (IRSL) dates (Krbetschek et al., 2002; Schwamborn et al., 2002) were also used to constrain the sediments. The IRSL dating was carried out at the Quaternary Geochronology Section of the Saxonian Academy of Science in Freiberg, Germany, using the potassium feldspar coarse-grain technique. Short-term and long-term fading tests performed in Freiberg did not show any strong variations.

One horizon of frozen peat was sampled for dating with ${ }^{230} \mathrm{Th} / \mathrm{U}$ disequilibria methods with a thermal ionization mass spectrometer (TIMS) at the Leibniz Institute for Applied Geoscience (GGA), Hannover. The ${ }^{230} \mathrm{Th} / \mathrm{U}$ ages were determined assuming a closed system and negligibly small ${ }^{230} \mathrm{Th}$ initial contents. The ${ }^{230} \mathrm{Th} /{ }^{232} \mathrm{Th}$ activities of 0.6 suggested contaminations with detritic ${ }^{230} \mathrm{Th}$. Therefore, an isochrone correction of three subsamples was necessary (Geyh, 1994). Sampling and dating methods are described in detail by Schirrmeister et al. (2002a).

Various sedimentological techniques were used to characterize and differentiate the permafrost deposits. Grain size analyses were performed with a laser particle analyzer LS 200 (Fa. Beckman-Coulter). The total organic carbon (TOC) content was measured with a CNS Elementar Analyzer VARIO-EL-III. $\delta^{13} \mathrm{C}$ values of TOC were measured with a Finnigan DELTA $S$ mass spectrometer. The mass specific magnetic susceptibility was determined using BARTINGTON MS2 and MS2B instruments. Mass-specific magnetic susceptibility is determined by the content of magnetic minerals in the sediment and is often used for paleoenvironmental studies of terrestrial Late Quaternary series, e.g., loess-paleosol sequences (Kukla et al., 1988; Grimley et al., 1998).

Heavy mineral analysis was used on the 63 to $125 \mu \mathrm{m}$ subfraction. Sample preparation was performed according to standard procedures (Boenigk, 1983; Mange and Maurer, 1992). Heavy minerals were separated using a sodium metatungstate solution $\left(\mathrm{Na}_{6}\left(\mathrm{H}_{2} \mathrm{~W}_{12} \mathrm{O}_{40}\right) \times \mathrm{H}_{2} \mathrm{O}\right)$ with a density of $2.89 \mathrm{~g} / \mathrm{cm}^{3}$. On average 200 to 300 transparent grains were counted on slides. Results are expressed in grain $\%$.

Oxygen and hydrogen isotope measurements of ice wedges and snow samples were carried out on a Finnigan MAT Delta-S mass spectrometer using the common equilibration technique. After equilibration of the water sample (with $\mathrm{H}_{2}$ or $\mathrm{CO}_{2}$ ), the equilibrated gas is transferred to the mass spectrometer using the dual inlet method and measured 10 times against a reference gas, and is then displayed as per mil differences relative to $\mathrm{V}$-SMOW. The internal $1 \sigma$ error is generally better than $0.8 \%$ for $\delta \mathrm{D}$ and better than $0.1 \%$ for $\delta^{18} \mathrm{O}$ for all measurements (Meyer et al., 2000).

Pollen samples were prepared using standard techniques (Faegri et al., 1989). For each sample, 200-300 terrestrial pollen grains and spores were counted at $400 \times$ magnification. The relative frequency of pollen was calculated based upon the tree and herb pollen sum. The percentage of spores, redeposited taxa, and algae was calculated based on the sum of pollen and the respective group (e.g., pollen + spores; pollen + algae, etc.) (Berglund and Ralska-Jasiveczowa, 1986). For graphic representation of the pollen data, the THILIA software was used (Grimm, 1991).

We also analyzed rhizopods to characterize paleosol conditions. The significance of rhizopod analysis for paleoecological studies is based on the fact that testate amoebae are permanently attached to the substrate. Commonly their testa are destroyed if 
sediments are redeposited. Therefore, these testa indicate the in situ paleoenvironmental conditions during sedimentation, unlike many other biological remains.

Samples for testate amoebae analyses were sieved with a $500 \mu \mathrm{m}$ mesh and the testa were concentrated with a centrifuge. A drop of suspension was placed on a slide and mixed with glycerol. Normally, five subsamples were examined at X200-400 magnification on the light microscope.

\section{DESCRIPTION OF THE STUDY PROFILES: DEPOSITS AND DATING}

\section{Section A (Nagym, Ebe-Basyn-Sise Island)}

The section is located on the northern bank of the Olenyeksky branch on Ebe-Basyn-Sise Island near the small settlement Nagym, western Lena Delta $\left(72^{\circ} 52^{\prime} 46^{\prime \prime} \mathrm{N}, 123^{\circ} 19^{\prime} 20^{\prime \prime} \mathrm{E}\right)$. The cliff consists mainly of a sandy unit covered by the Ice Complex unit (Fig. 2). The sandy unit is 10 to $20 \mathrm{~m}$ thick and is subdivided into two main parts with six sublayers (Table 1). The lower part (0-6 $\mathrm{m}$ above the river) consists of alternating fine- to medium-grained sand layers and contains horizons with plant remains and peaty sand (Fig. 3A). Fine lamination (1-3 mm thick) and numerous vertical roots of Equisetum probably reflect shallow water accumulation conditions, typical for point bars. The abundance of plant remains decreases with the profile height.

The upper horizon of the sandy unit ( $6 \mathrm{~m}$ to max. $20 \mathrm{~m}$ above the river) consists of fine-grained silty sand with some interlayers of medium-grained sand and gravels. Current marks - e.g., ripples and small channel casts filled with organic detrituswere observed in this layer. While this horizon contains layers with roots of shrubs, the abundance of plant remains is generally lower than in underlying sediments. The ice content of the sandy unit is low (between 20 and $37 \mathrm{wt} \%$ relative to the dry sample weight) and the cryostructure is massive (van Everdingen, 1998) or structureless (French, 1996). A few small ice wedges about $10 \mathrm{~cm}$ wide occur in the lower organicrich sands (Fig. 3B) and terminate in the covering sediment. Additionally, some fissures filled with ice were found in the lower horizon.

According to IRSL age determinations, the sands were accumulated between $57 \pm$ $9 \mathrm{ka}$ and $49 \pm 22 \mathrm{ka}$ (Krbetschek et al., 2002). AMS radiocarbon ages from this unit $(53+3.9 /-2.6 \mathrm{ky} \mathrm{BP}$ and $>54 \mathrm{ky} \mathrm{BP})$ do not contradict the IRSL ages (Tables 1 and 2).

The change to the overlying Ice Complex unit is clearly expressed in lithology and geocryology. This concerns the occurrence of small peat inclusions, larger peat lenses, and several buried cryosols covering the sandy unit, as well as increasing ice contents. At this sharp boundary a brownish-grey cryoturbated peaty paleosol, $\sim 0.5-$ $1 \mathrm{~m}$ thick, is found at various sites at $\sim 13-15 \mathrm{~m}$ above the river level. The Ice Complex consists mainly of fine- to medium-grained sand and silt, and is rich in plant detritus, twigs and tiny roots, peat lenses, and paleosols. The cryostructure is characterized by ice bands of $\sim 2-5 \mathrm{~cm}$ thickness along with lens-like ice reticulations in sediment interlayers. The gravimetric ice content relative to the sample weight is between 60 and $380 \mathrm{wt} \%$. The ice wedges of the Ice Complex are 3-5 m in width at the top of the section and penetrate a few meters deep into the lower sands, with widths between 0.5 and $0.7 \mathrm{~m}$. The "roots" of the ice wedges consist of vertical 


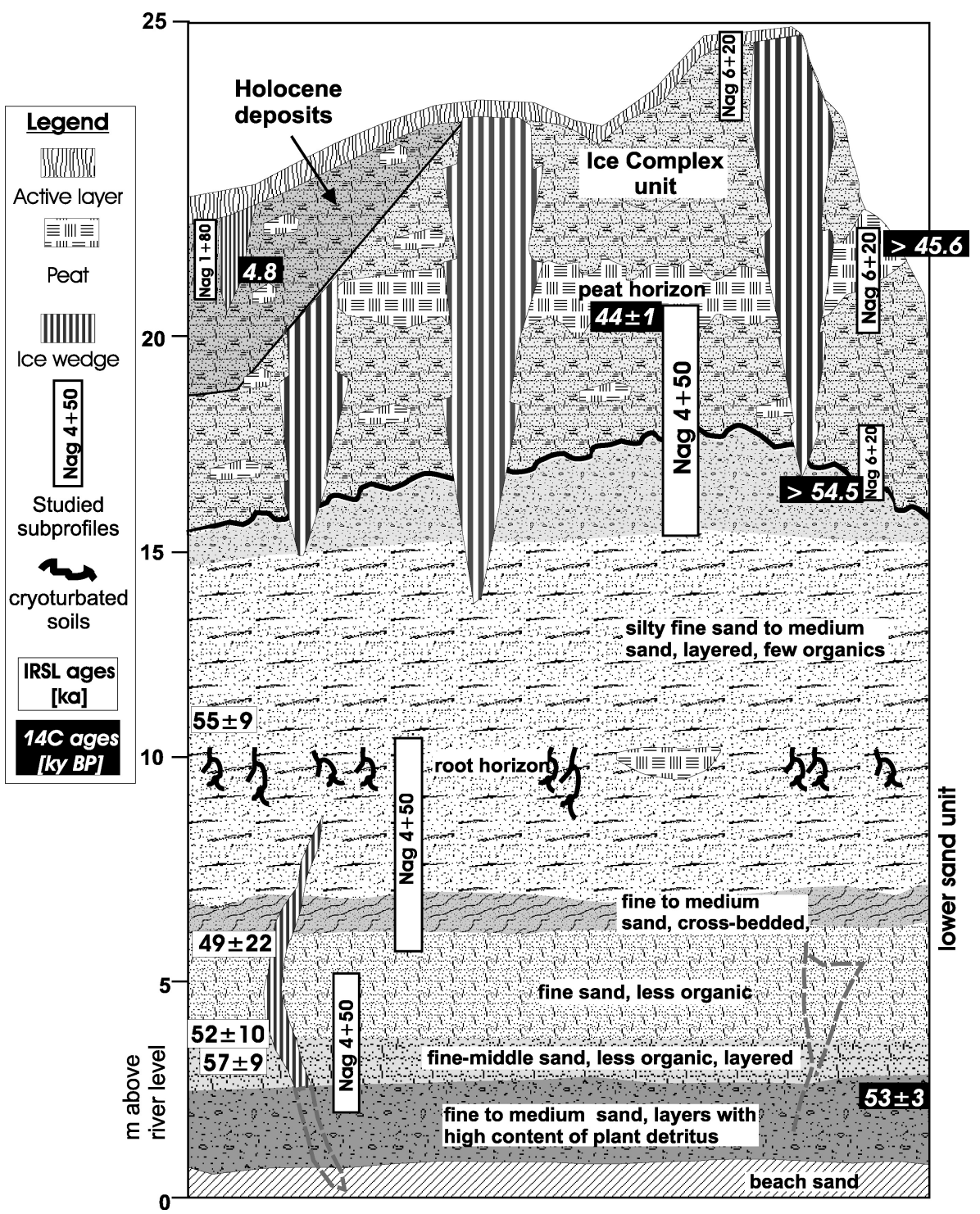

Fig. 2. A typical permafrost deposit profile from the northern side of the Olenyeksky distributary near Nagym (section A).

alternations of $1 \mathrm{~cm}$ wide bands of ice and sediment. The ice wedges are vertically banded and contain numerous gas bubbles. They have symmetrical shoulders in contact with surrounding sediments. This feature, together with the ice properties of segregated ice (bands, lens-like reticulated cryostructure, oversaturated ice content) reflects the simultaneous formation of ice wedges and permafrost deposits (Washburn, 1979; Melnikov and Spesivtsev, 2000). The radiocarbon ages of the Ice Complex deposits were determined with $42.9+3.1 /-2.2 \mathrm{ky}$ BP (11 m above the river), $44.2+1 /-0.9$ ky BP (21.2 $\mathrm{m}$ above the river), and $>45.6 \mathrm{ky} \mathrm{BP}($ Table 1$)$. 


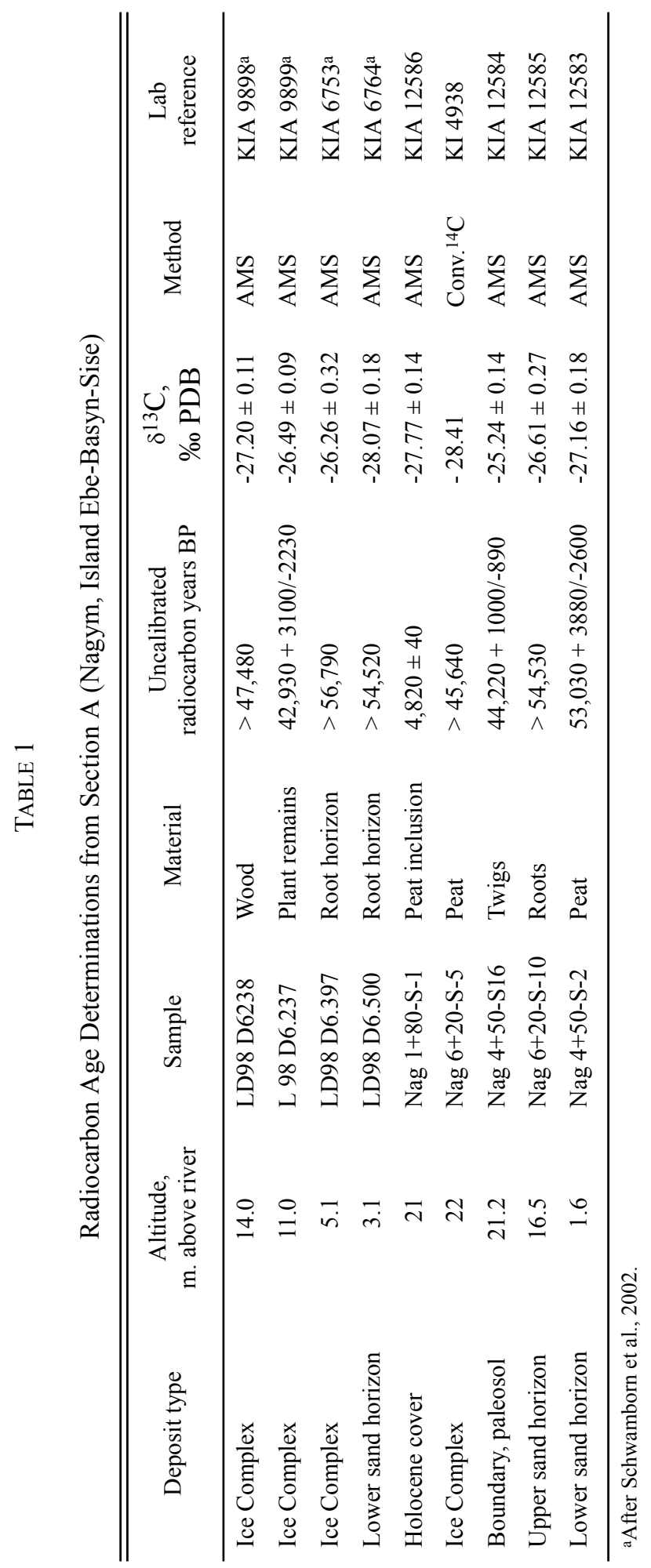



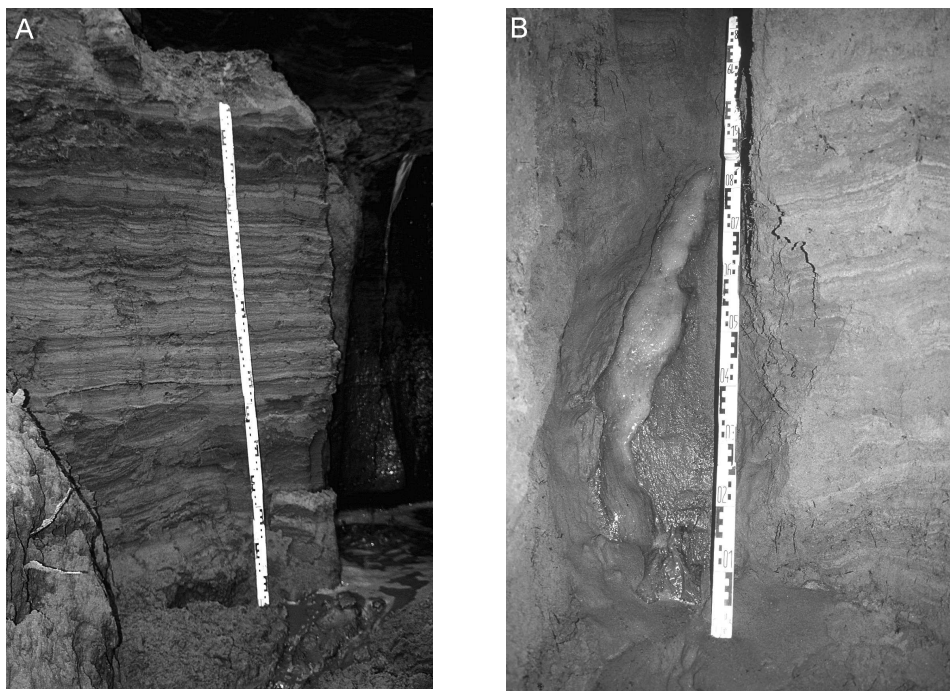

Fig. 3. Sediment and cryogenic structures of the lower sandy unit in section A (Nagym). A. Well-layered, fine- to medium-grained sands and a small ice wedge on the right hand side (detail in Fig. 3B). B. A small ice wedge from the lower sand unit in section A.

TABLE 2

IRSL Age Determinations from the Sand Unit of Section A (Nagym, Island Ebe-Basyn-Sise)

\begin{tabular}{ccl}
\hline \hline Altitude, $\mathrm{m}$ above river & Sample & IRSL age, years \\
\hline 10.3 & Ole 6 & $55,000 \pm 9,000$ \\
5.8 & Ole 3 & $49,000 \pm 22,000$ \\
3.95 & Ole 2 & $52,000 \pm 10,000$ \\
3.4 & Ole 1 & $57,000 \pm 9,000$ \\
\hline
\end{tabular}

Source: Krbetschek et al., 2002.

In some places 1 to $3 \mathrm{~m}$ thick Holocene deposits cover the Ice Complex unit. They consist of cryo-turbated, brownish-black, silty sand with numerous small peat inclusions, and are characterized by smaller white ice wedges ( $1 \mathrm{~m}$ wide, $3 \mathrm{~m}$ long). Peat inclusions were radiocarbon dated to $4.82 \pm 0.04 \mathrm{ky} \mathrm{BP}$ (Table 1).

\section{Section B (Buor Khaya, Kurungnakh Island)}

The section is located in the central Lena Delta at the eastern bank of Kurungnakh Island between $72^{\circ} 20^{\prime} 00^{\prime \prime} \mathrm{N}, 126^{\circ} 17^{\prime} 16^{\prime \prime} \mathrm{E}$ and $72^{\circ} 21^{\prime} 02^{\prime \prime} \mathrm{N}, 126^{\circ} 19^{\prime} 16^{\prime \prime E}$. (Fig. 1). Generally, the sedimentary succession is similar to section A (Fig. 4). Ice Complex deposits overlie a 15 to $20 \mathrm{~m}$ thick sandy unit. This unit consists of fine-layered 


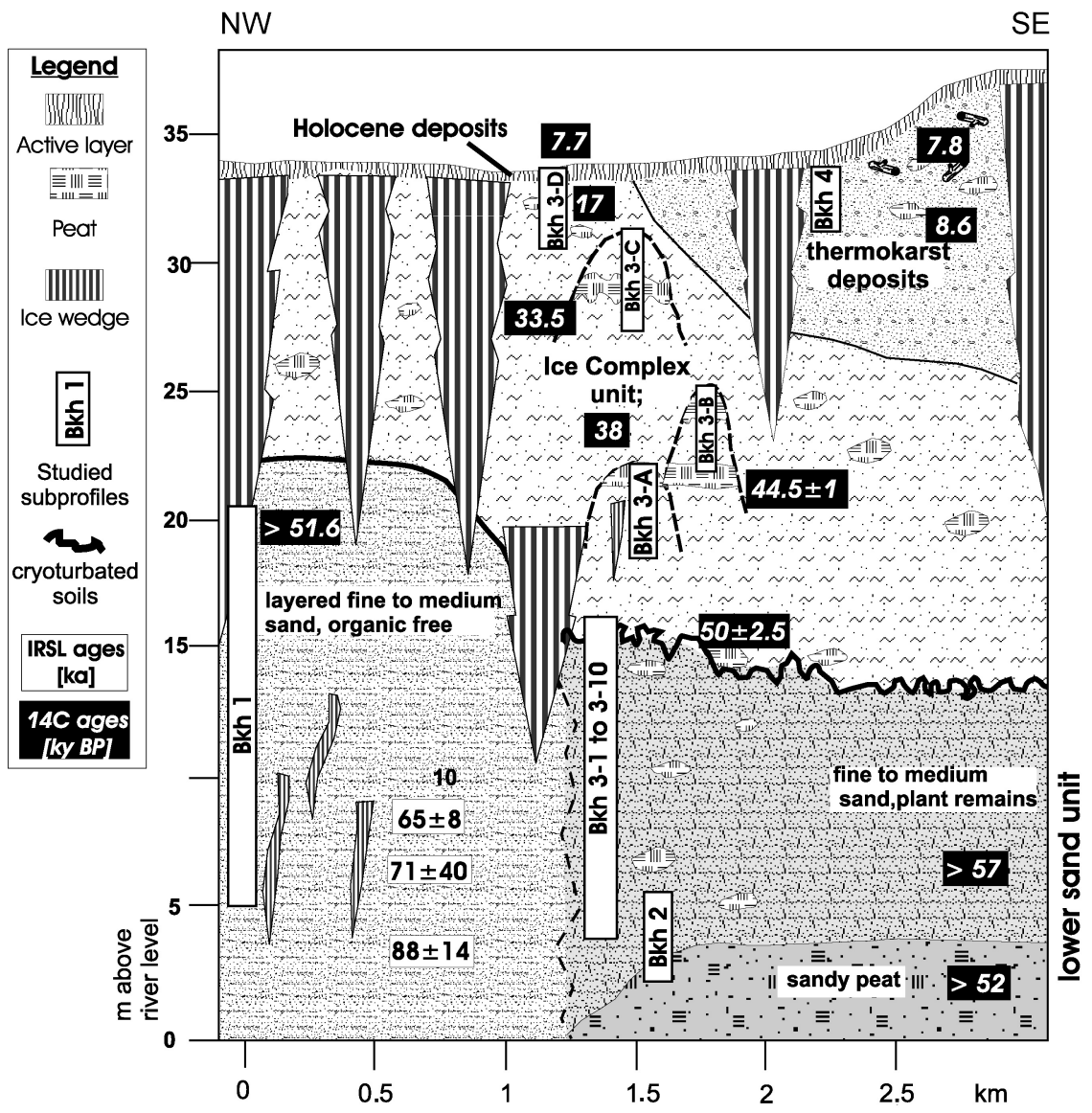

Fig. 4. A typical permafrost deposit profile from Kurungnakh Island in the central Lena Delta at the Olenyeksky distributary (section B).

alternations of medium-grained to fine-grained sands and silty sands without organic matter. The sands contain only a few narrow ice wedges. The cryostructure is mostly massive. Large ice wedges from the Ice Complex deposits penetrate into the lower sand unit (Fig. 5). Small channel casts $\sim 0.3 \mathrm{~m}$ wide, filled with fine laminated organic detritus, occur repeatedly in the uppermost sand horizon near the Ice Complex deposit contact. These plant remains were radiocarbon dated to $>51.7 \mathrm{ky}$ BP (Table 3). In another section, $2 \mathrm{~km}$ to the east, a $3 \mathrm{~m}$ thick horizon with 5 to $1 \mathrm{~cm}$ alternating layers of sand and peat is covered by 10 to $12 \mathrm{~m}$ thick fine laminated sands that contain bark-covered shrubby twigs and vertical autochthonous roots (Fig. 4). The lamination reflects very shallow water accumulation conditions of a river point bar. This horizon is comparable with the lower sand horizon of section A. According to IRSL age determinations, the sandy unit was formed between $88 \pm 14$ and $65 \pm 8 \mathrm{ka}$ (Krbetschek et al., 2002; Table 4).

A cross-bedded, $0.5 \mathrm{~m}$ wide channel cast is visible at the boundary between the sandy unit and the Ice Complex unit about 12 to $15 \mathrm{~m}$ above the river level. 

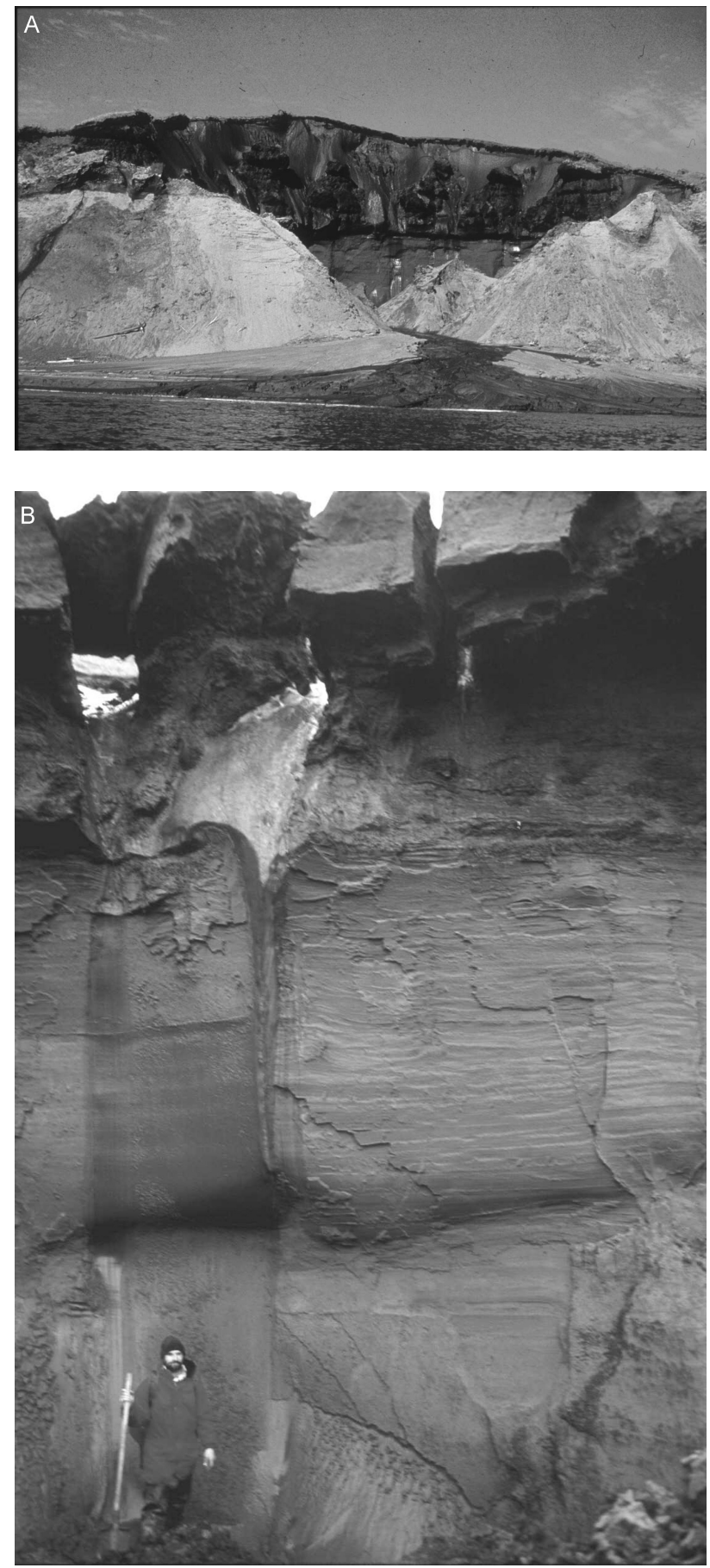

Fig. 5. Ice Complex deposits with large ice wedges that cover the sandy unit on the east coast of section B (Buor Khaya, Kurungnakh Island). A. General view of a coastal outcrop. B. Contact between the lower sand unit and the Ice Complex deposits. 
TABLE 4

IRSL Age Determinations from the Sand Unit of Section B

(Buor Khaya, Island Kurungnakh-Sise)

\begin{tabular}{clc}
\hline \hline $\begin{array}{c}\text { Altitude, } \\
\text { m above river }\end{array}$ & Sample & $\begin{array}{c}\text { IRSL age, } \\
\text { years }\end{array}$ \\
\hline 8.85 & Ole 10 & $65,000 \pm 8,000$ \\
5.7 & Ole 8 & $71,000 \pm 40,000$ \\
4.3 & Ole 7 & $88,000 \pm 14,000$ \\
\hline
\end{tabular}

Source: Krbetschek et al., 2002.

Additionally, a strongly cryoturbated $1 \mathrm{~m}$ thick silty-sandy paleosol with involutions and peat inclusions was found within the syngenetic permafrost. The radiocarbon age of a peat inclusion is $50.1+2.8 /-2.1 \mathrm{ky} \mathrm{BP}$ (Table 3 ).

The lower part of the Ice Complex contains several 0.5 to $0.7 \mathrm{~m}$ thick layers and lenses of moss (Drepanocladus) peat. The sediment between peat layers and lenses consists of grey silty sand with numerous vertical grass roots and small twigs. The cryostructure is characterized by $1-2 \mathrm{~cm}$ thick ice bands and lens-like reticulations. Large ice wedges (about $20 \mathrm{~m}$ long and 5 to $7 \mathrm{~m}$ wide) are common, and in a few thermokarst mounds contain additional small ice wedges $(10$ to $20 \mathrm{~cm}$ wide, 1 to $3 \mathrm{~m}$ long) of a younger generation. Peaty paleocryosols were also observed in the upper part of the Ice Complex, but the peat horizons and lenses there are not as thick as in the lower part. The $15 \mathrm{~m}$ thick Ice Complex deposits were probably formed between $44.5+1.5 /-1.2 \mathrm{ky} \mathrm{BP}$ and $16.98+0.09 /-0.08 \mathrm{ky}$ BP according to radiocarbon ages. Younger Ice Complex deposits were not found in the section. The Ice Complex deposits are covered by Holocene deposits dated to $7.77 \pm 0.04$ ky BP (Table 3).

In some places Holocene thermokarst deposits occur at the top of the section. They consist of alternating cryoturbated medium-grained sands and silty sands and contain numerous plant remains like trunks of tree such as birch $(8.68 \pm 0.14 \mathrm{ky} \mathrm{BP})$ and alder $(7.59 \pm 0.14 \mathrm{ky} \mathrm{BP})$ and peat inclusions. This horizon contains ice wedges of about 3 to $5 \mathrm{~m}$ width, which is comparable with the ice wedge sizes in the Ice Complex described above.

\section{Section C (Sasyr, Dzhangylakh Island)}

A combined profile of two overlapping sites was studied on the left bank of the Arynsky distributary about $100 \mathrm{~km} \mathrm{NW}$ of section B (72 $\left.38^{\prime} 40^{\prime \prime} \mathrm{N}, 125^{\circ} 30^{\prime} 58^{\prime \prime} \mathrm{E}\right)$ (Fig. 1). The Ice Complex unit overlies a sand unit, which is subdivided into three horizons (Fig. 6).

A lower sand horizon (0 to $3.4 \mathrm{~m}$ above the river) consists of fine- to mediumgrained sand. The horizontal bed of grey sand is mainly formed of quartz and micas. The cryostructure is structureless (French, 1996) or massive (van Everdingen, 1998). These deposits include small $(1.5$ to $5 \mathrm{~cm})$ organic-rich interlayers and a $15 \mathrm{~cm}$ thick layer of ice-rich granular greenish-gray silt. The content of plant remains (brownish 


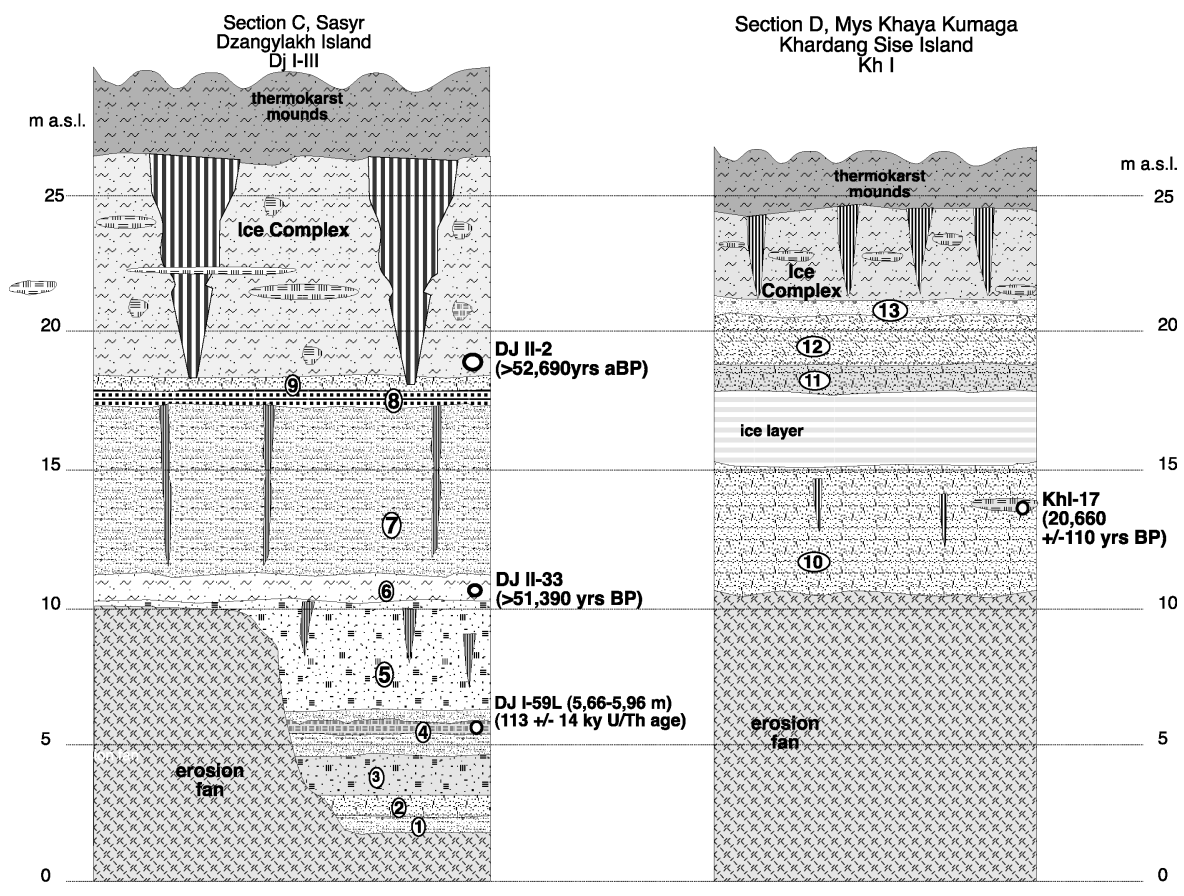

Fig. 6. Profiles of permafrost deposits from section $\mathrm{C}$ of Dzhangylakh Island (Sasyr) and section D of Mys Khaya on Khardang Island on the Arynsky distributary. Legend: 1 = finegrained sand; 2 = fine-grained sand with plant remnants; 3 = peaty fine-grained sand; 4 = peatfine-grained sand interbedding; $5=$ bedded peaty, fine-grained sand; $6=$ silty fine-grained sand with few plant remains; $7=$ medium-grained sand; $8=$ ice with sandy interlayers; $9=$ fine- to coarse-grained sand and gravel; $10=$ medium-grained sand with few plant remnants; $11=$ silty fine-grained sand with peat; 12 = silty fine-grained sand; 13 = ice-rich, silty fine-grained sand with plant remains.

roots, black twigs) increases in the upper part of this horizon. The cryostructure of this sequence is banded (up to $2 \mathrm{~cm}$ thick ice bands) and (lens-like) reticulated.

Fine- to medium-grained, horizontally bedded grey sand layers 1 to $3 \mathrm{~cm}$ thick and $1 \mathrm{~cm}$ thick layers of slightly decomposed Hypnum peat alternate in this horizon. It also contains 10 to $20 \mathrm{~cm}$ thick intercalated sand and peat layers. The cryostructure is massive (structureless). The isochrone-corrected ${ }^{230} \mathrm{Th} / \mathrm{U}$ age of sample DJI-50L, 5.66-5.96 m collected in this horizon is $113 \pm 14 \mathrm{ka}$ (Table 5).

The peat-sand interbedding between 6.4 and $10.3 \mathrm{~m}$ above the river consists of 1 to $7 \mathrm{~cm}$ thick interlayers and 15 to $25 \mathrm{~cm}$ broad ice wedges. These milky ice wedges contain gas bubbles and fine-grained sand. The peat and sand layers bend upwards at the contact zones between ice wedges and frozen deposits. The contact zones are brownish colored by infiltrated iron oxide. The upper sediment of the 10.3 to $11.3 \mathrm{~m}$ thick horizon consists of horizontal-wavy silty sand with plant macrofossils radiocarbon dated to $>51.4 \mathrm{ky} \mathrm{BP}$ (Table 6). This upper part is a gradual transition from the peat-sand interbedding to sand deposits of the next horizon (11.3 to $18.5 \mathrm{~m})$, which is 
TABLE 5

Data of the ${ }^{230} \mathrm{Th} / \mathrm{U}$ Age Determination of Three Subsamples from a Peat Horizon of Section C (Dzhangylakh Island, Sasyr)

\begin{tabular}{lcccccc}
\hline \hline $\begin{array}{c}\text { Sample no., } \\
\text { TIMS-Hv }\end{array}$ & $\begin{array}{c}234 \mathrm{U} / 238 \mathrm{U}, \\
\pm 2 \sigma\end{array}$ & $\begin{array}{c}{ }^{230} \mathrm{Th} / 232 \mathrm{Th}, \\
\pm 2 \sigma\end{array}$ & $\begin{array}{c}\mathrm{U} \text { conc., } \\
\mathrm{ppm}\end{array}$ & $\begin{array}{c}\text { Th conc., } \\
\mathrm{ppm}\end{array}$ & $\begin{array}{c}{ }^{230} \mathrm{Th} / \mathrm{U} \text {-age, } \\
10^{3} \mathrm{yr} \pm 2-\end{array}$ & $\begin{array}{c}\text { Isochrone-corr. } \\
{ }^{230} \mathrm{Th} / \mathrm{U}-\mathrm{age}, \\
10^{3} \mathrm{yr} \pm 2 \sigma\end{array}$ \\
\hline 478 & $1.292 \pm 0.004$ & 0.52 & 0.55 & 4.00 & $401+30 /-30$ & $110+25 /-21$ \\
479 & $1.287 \pm 0.008$ & 0.56 & 0.62 & 4.02 & $340+28 /-23$ & $115+23 /-29$ \\
480 & $1.308 \pm 0.006$ & 0.51 & 0.57 & 4.44 & $>500$ & $115+28 /-22$ \\
Isochrone & & & & & & $113 \pm 14$ \\
\hline
\end{tabular}

more homogeneous and consists of fine- to medium-grained, grey, quartz-feldspar sands, which are horizontally bedded to wavy. Only a few layers of coarse-grained sand and gravel are visible. The cryostructure is massive.

Small transparent ice wedges ( $35 \mathrm{~cm}$ wide) with gas bubbles cut this unit between 12 and $17.5 \mathrm{~m}$ above the river. In addition, a horizontal interlayer of ice was observed between 17.6 and $18.2 \mathrm{~m}$ above the river. This ice layer is rich in gas bubbles and contains $2 \mathrm{~cm}$ thick interlayers of fine- to coarse-grained sand. Alternations of fine- and coarse-grained sand and gravel form the uppermost part of the sand unit. There is a sharp, horizontal contact to the Ice Complex horizon with a clear difference in color and lithological composition. The Ice Complex (18.5-26.5 $\mathrm{m}$ above the river) consists of ice-rich, horizontal-wavy silty sands with many peat inclusions and peat lenses. Large ice wedges cut this horizon. The radiocarbon dates indicate that the lowest part is older than 52.7 ky BP (Table 6). Numerous thermokarst mounds (baydzhar$a k h s$ ) are common on the slope between $27 \mathrm{~m}$ (the top of the profile) and $41 \mathrm{~m}$ above the river level. Thermokarst mounds are characteristic for the Ice Complex deposits at this level.

\section{Section D (Mys Khaya Kumaga, Khardang Sise Island)}

The fourth section (Figs. 6 and 7) is located on the northeastern part of the Khardang Sise Island, on the left bank of the Arynsky distributary ( $72^{\circ} 53^{\prime} 15^{\prime \prime} \mathrm{N}, 125^{\circ}$ 11'40" E) (Fig. 1). The cliff consists mainly of sandy deposits covered by Ice Complex deposits. The lower $11 \mathrm{~m}$ portion of the section is buried under a sediment fan. The lower sandy unit (11.0-14.8 $\mathrm{m}$ above the river) consists of fine- to mediumgrained, horizontal-wavy yellow sands with few plant macrofossils. Separate, 2 to $4 \mathrm{~cm}$ thick interlayers of brownish silty sand and a small peat lens were also visible at $13.0 \mathrm{~m}$ above the river. Plant remains from between 13.05 and $13.10 \mathrm{~m}$ were radiocarbon dated to $20.66 \pm 0.11 \mathrm{ky} \mathrm{BP}$ (Table 6). The sandy unit contains a $45 \mathrm{~cm}$ thick ice wedge. The cryostructure of this unit is massive. An ice layer occurs between 14.8 and 16.4 to $17.2 \mathrm{~m}$ above the river with an inclination of 45 to $50^{\circ}$ to the horizontal. The sandy unit continues with alternations of yellow fine-grained sand and brownish peat and silty sand layers (up to $12 \mathrm{~cm}$ thick) to $18.2 \mathrm{~m}$. The next horizon (18.2 to $20.1 \mathrm{~m}$ above the river) consists of alternations of fine-grained sand and 
SCHIRRMEISTER ET AL.

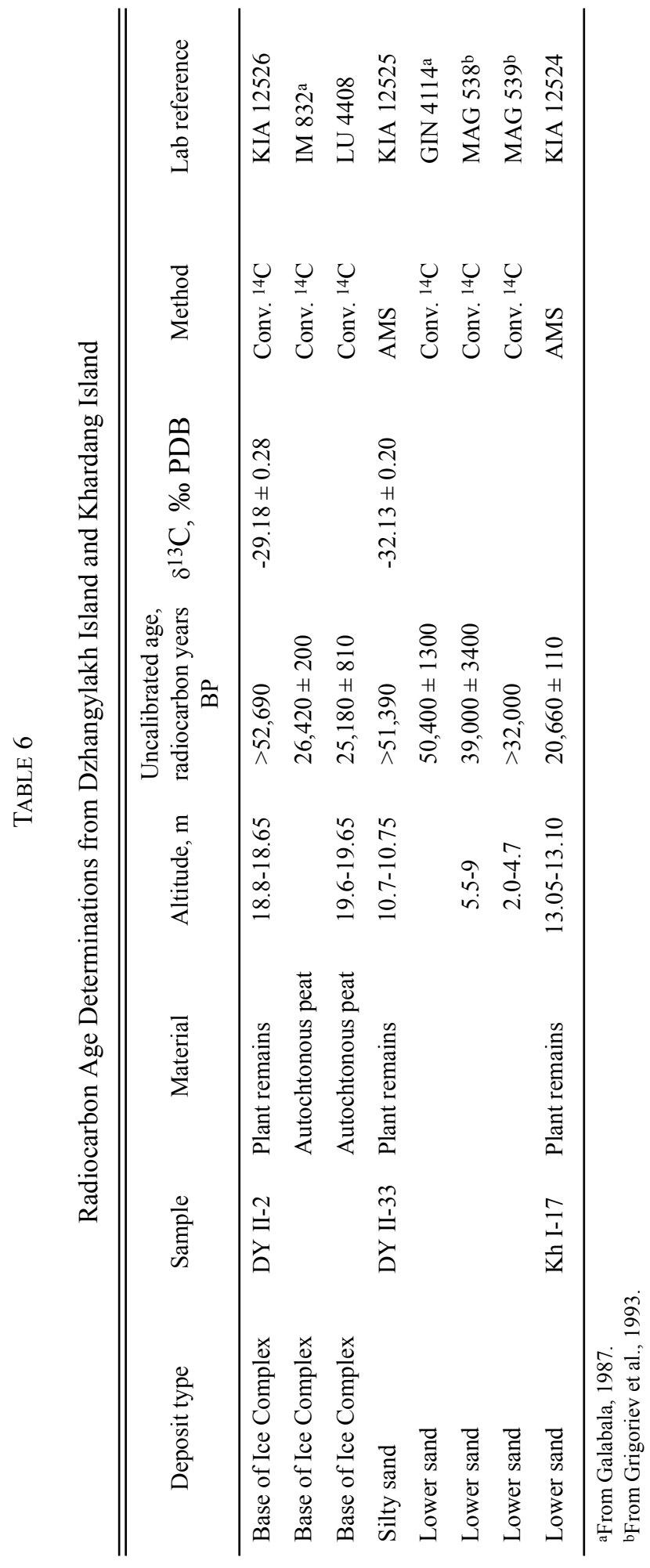


A
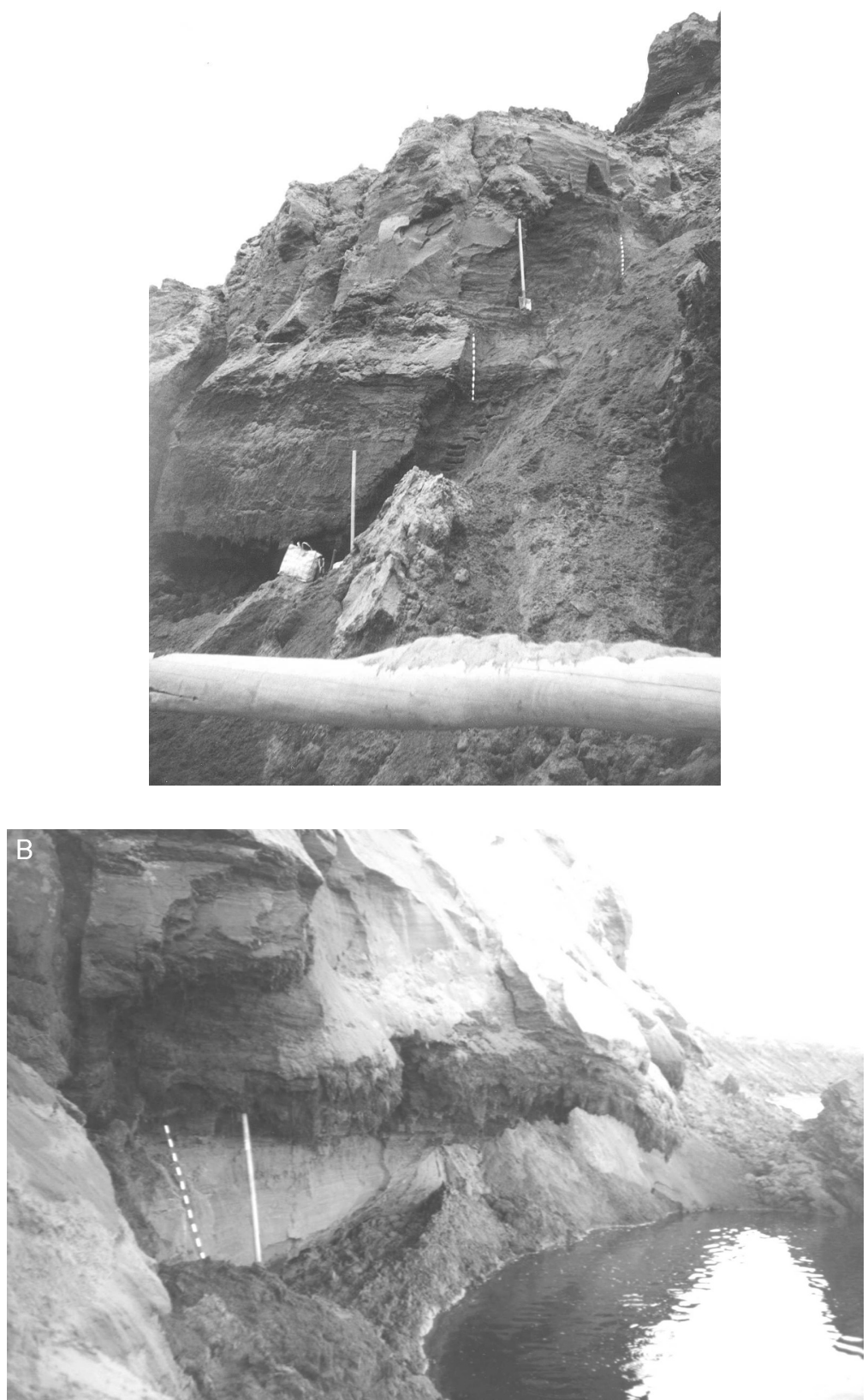

Fig. 7. Structure of the lower sand unit at section C (Sasyr, Dzhangylakh Island). A. General view of the well-layered lower sand unit at the Arynsky distributary. B. Horizon of lowermost sandy peat layer, $\mathrm{U} / \mathrm{Th}$ dated to $113 \pm 14 \mathrm{ka}$. 


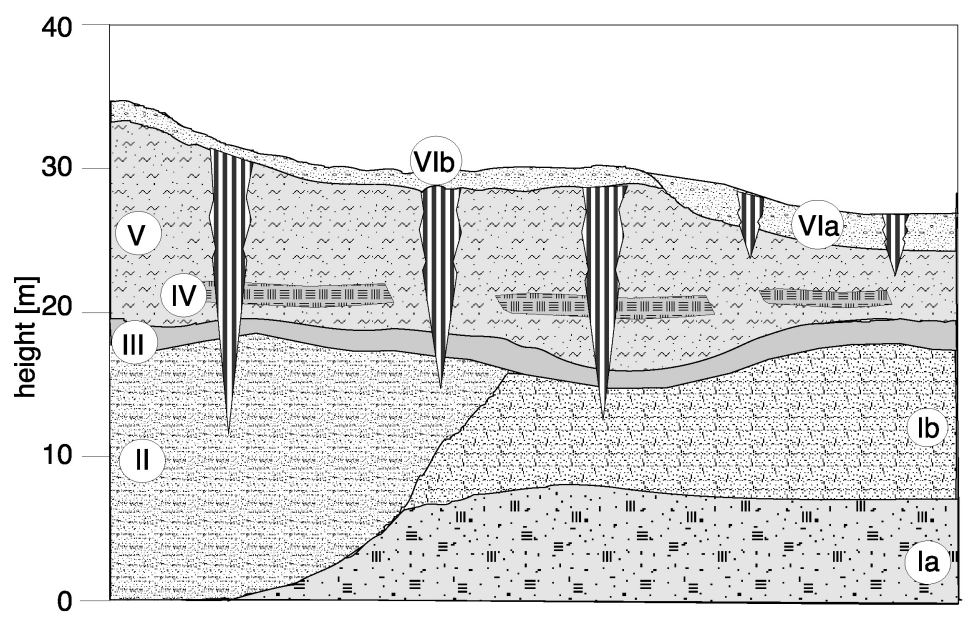

Fig. 8. Generalized section of the studied sites in the Chekanovsky Ridge foreland. Legend: $\mathrm{I}=$ old branch deposits ( $\mathrm{a}=$ peat-sand interbedding, $\mathrm{b}=$ organic-bearing sand); $\mathrm{II}=$ point bar sand; III = cryoturbated paleosol; IV = peat layer; V = Ice Complex deposits; VI = Holocene deposits $(\mathrm{a}=$ thermokarst deposits, $\mathrm{b}=$ surface layer $)$.

brownish silty sand. The cryostructure is massive. A $20 \mathrm{~cm}$ thick layer of ice-rich and ice-banded silty sand with plant remains was observed at the boundary between the sandy deposits and Ice Complex deposits. The next unit, between 20.3 and $24 \mathrm{~m}$ above the river, contains well-decomposed black to brown peat layers alternating with ice lenses and silty sand. The cryostructure is banded and lens-like reticulated. Small thermokarst mounds cover the section above $24 \mathrm{~m}$ to $25.4 \mathrm{~m}$.

The detailed profile descriptions are summarized in a columnar section in Figure 8 . The general sequence of fluvial sands covered by Ice Complex deposits, which were partly eroded by thermokarst and covered by Holocene deposits, is widely distributed in the accumulation plain in front of the Chekanovsky Ridge. Various fluvial facies composed the lower sandy unit. The bedded peaty sands and organic rich sand reflect shallow water conditions, probably of an old river branch. These layers were partly eroded down to the river level and covered by point bar sands. Ice Complex deposits overlie the entire sandy unit. A cryoturbated 0.5 to $1.0 \mathrm{~m}$ thick paleosol was formed at this boundary, reflecting a long period of stable surface conditions. Peat layers, up to $1 \mathrm{~m}$ thick, frequently occur in the lower part of the Ice Complex unit. Holocene deposits cover both the Ice complex deposits of elevated sections (Yedoma) as well as Ice Complex deposits below thermokarst depressions (alasy).

\section{ANALYTICAL RESULTS}

\section{Sedimentological Characteristics}

Results of the sedimentological investigations of the two most thoroughly analyzed sections-Nagym, Ebe-Basyn-Sise Island (section A) and Buor Khaya, 

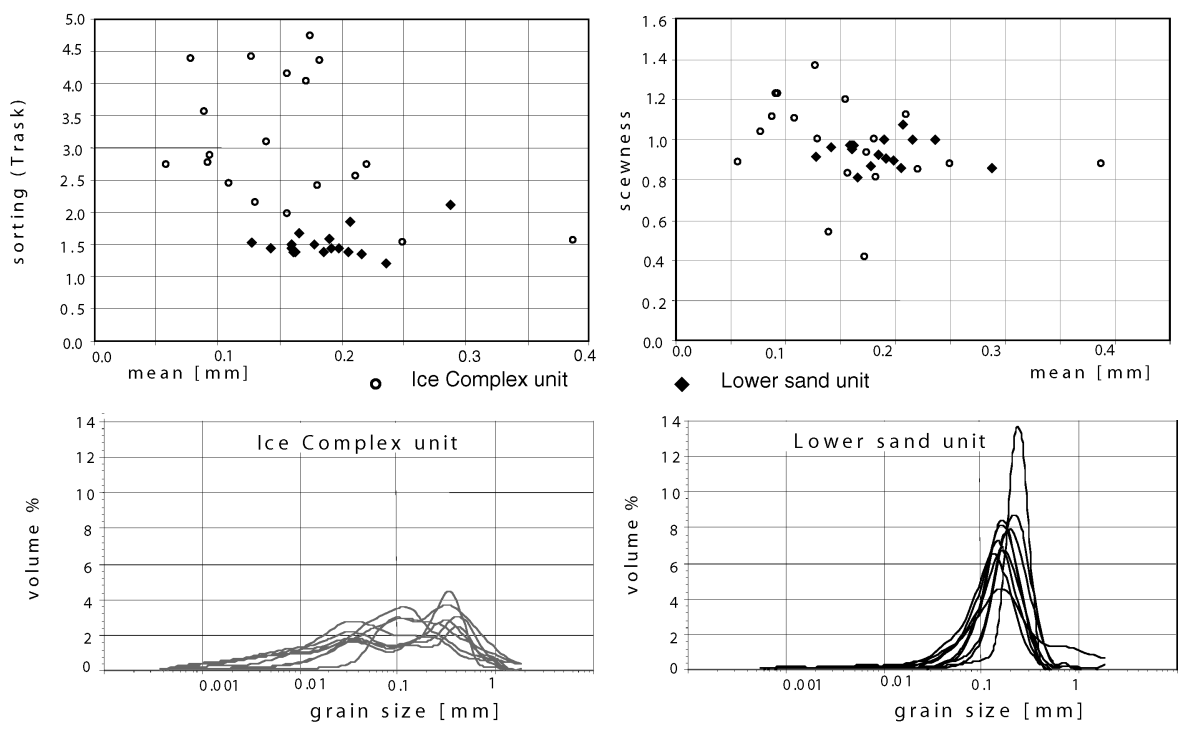

Fig. 9. Grain-size parameters and grain-size distribution of permafrost deposits from section A (Nagym).

Kurungnakh Island (section B) - are assumed to be representative for the entire study area. This assumption is based on the similar profile characteristics, as described above, numerous observations along the different river branches in the study area, as well as the published sediment descriptions of Galabala (1987), Grigoriev (1993), and Schwamborn et al. (2002). Analyses of grain-size composition, heavy mineral association, TOC-content, $\delta^{13} \mathrm{C}$ values, and mass-specific magnetic susceptibility helped to characterize the various depositional units.

Differences in the formation of the two sections are evident from grain size distribution curves (Figs. 9 and 10). Pure point bar sands are characterized by unimodal grain size frequency curves. Their average grain size varies between 0.15 and $0.25 \mathrm{~mm}$ and the degree of sorting (Trask's parameter) is moderate. The bedded sands with plant remains are characterized by trimodal curves, low degrees of sorting, and a wide range of average grain sizes (Figs. 9 and 10). The Ice Complex deposits show a typical grain size pattern of wide, multi-modal curves, with a relatively high content of small fractions. The average grain size varies between 0.03 and $0.4 \mathrm{~mm}$ and the degree of sorting is low. These patterns reflect the polygenetic character of these separate permafrost deposits, as different accumulation processes had participated in their formation such as alluvial and niveo-eolian processes.

Heavy mineral data of both units were compared with detritic samples from snow patches in the Chekanovsky Ridge, Chekanovsky brook sediments, and Lena delta deposits (Fig. 11). The sandy detritic components from the snow patch samples have a high content of epidote $(23 \%)$, garnet $(18 \%)$, and apatite $(15 \%)$. The snow patch sands contain considerable amounts of opaque minerals (14\%) and amphibole (11\%). Titanites are also present (7\%), along with zircon (4\%). Pyroxenes and zoisites were observed in small amounts $(\sim 3.5 \%)$, with corundum as an accessory mineral $(<2 \%)$. 

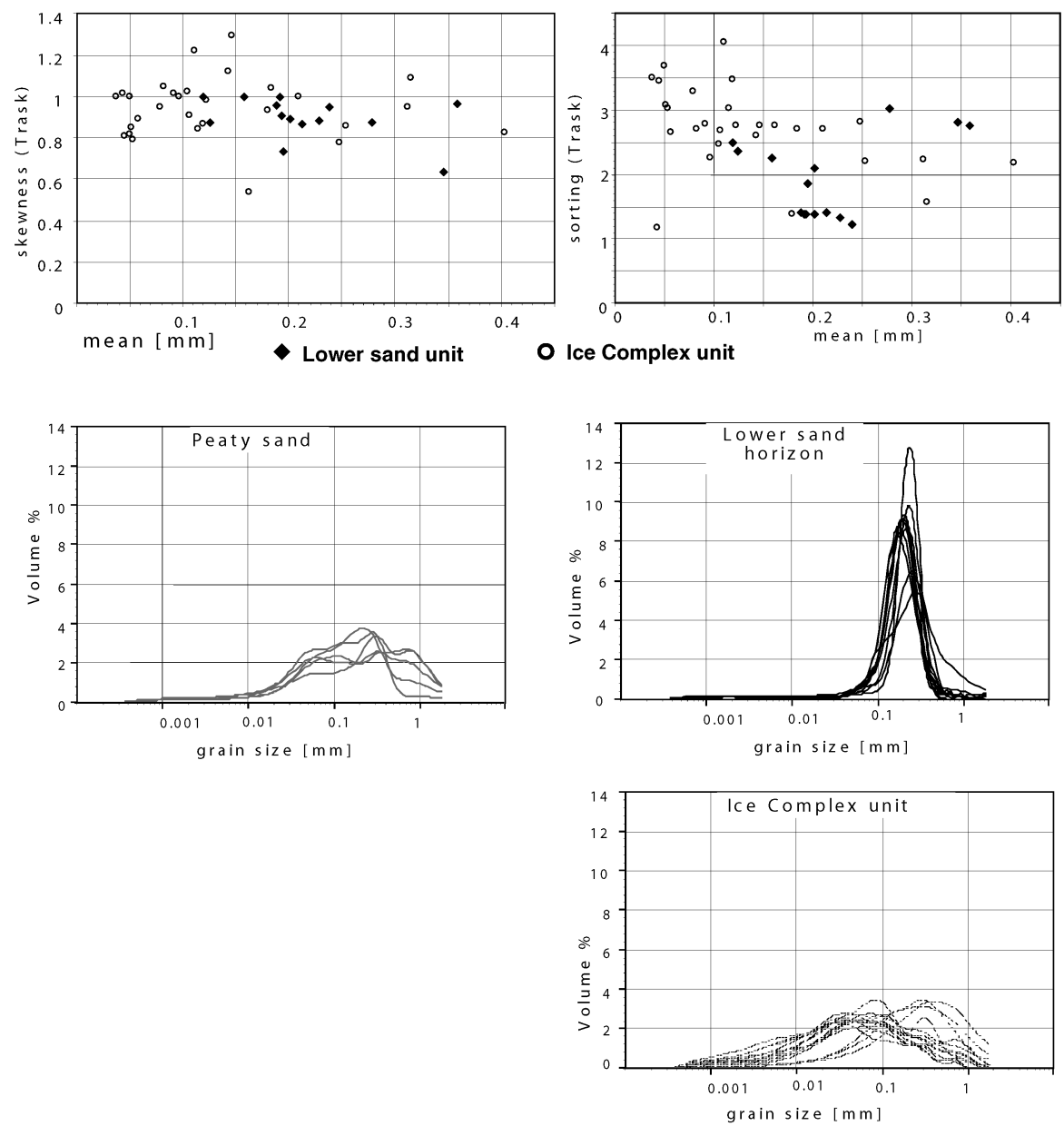

Fig. 10. Grain-size parameters and grain-size distribution of permafrost deposits from section B (Buor Khaya).

The heavy mineral composition of brook sediments from the Chekanovsky Ridge, south and southwest of the Lena Delta, shows very high amounts of garnet (45-65\%) and opaque grains (13-14\%). The amounts of amphibole, apatite, zoisite, and epidote are slightly different (6-8\%) than those of the snow patch sands.

The heavy mineral associations found in the Ice Complex deposits have a high content of garnet (25-26\%) and epidote (15-16\%). Amphibole and opaque grains are common (14-15\%). Both zoisite and apatite are frequently observed (4-12\%). In addition to zircon $(<2 \%)$, korund and tourmaline are found in accessory amounts. The Ice Complex sediments are poor in pyroxenes $(<2 \%)$. The heavy mineral composition in sediments of the Ice Complex exposed in the northern accumulation plain is similar to brook sediments of Chekanovsky outlets (Schwamborn et al., 2002). Based on this composition, the source area of the Ice Complex clastic material is most likely on the Chekanovsky Ridge. The detrital material from the snow patches and the Ice 


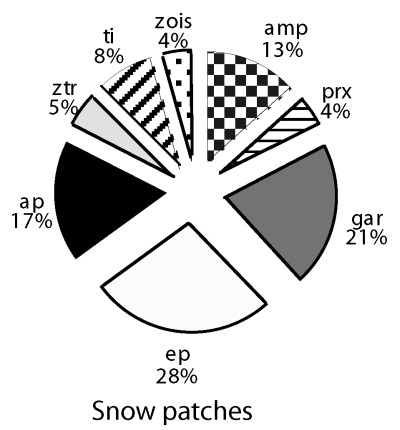

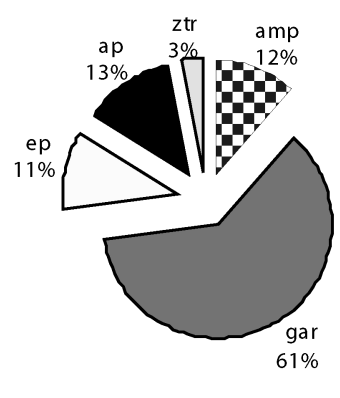

Chekanovsky outlets

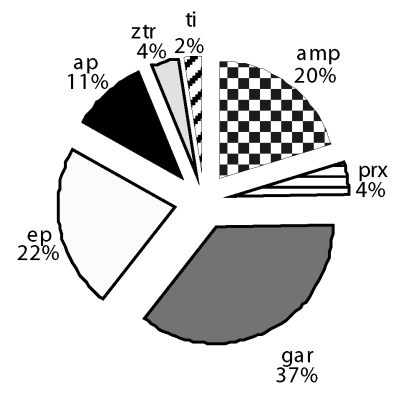

Ice Complex unit

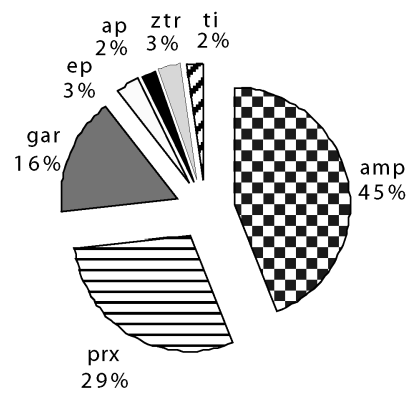

Lena River sand

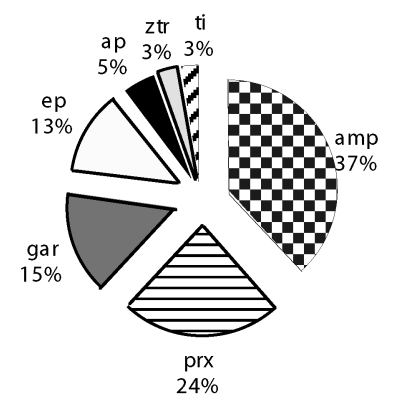

Lower sands unit

Fig. 11. Comparison of heavy mineral association of detritic snow-patch material from the Chekanovsky Ridge and Chekanovsky outlets with Ice Complex deposits and the heavy mineral association of recent Lena River sediments (Hoops, 2000) with the lower sand unit (Schwamborn et al., 2002). The compared mineral spectra consist of: amp = amphibole; $p r x=$ pyroxene; ztr $=$ zircon + tourmaline + rutile, gar $=$ garnet; ap $=$ apatite; zois $=$ zoisite, tit $=$ titanite.

Complex contain similar heavy mineral spectra, suggesting a common origin for both deposits. Changing hydrodynamic conditions may have caused variations in mineral frequency (for example garnet, epidote, and amphibole) and further modifications in relative proportions. Some less frequent minerals (for example titanite) may become physically shattered into smaller grain sizes during transport to the lowlands. In contrast, the sandy sediments, which underlie the Ice Complex deposits and are exposed along the Olenyeksky branch, show a heavy mineral composition similar to that of recent Lena River sediments (Schwamborn et al., 2002). They are characterized by an integrated heavy mineral composition due to the large catchment area of the Lena River that contains terrigeneous clastic and metamorphic rocks (Hoops, 2000). The sandy sediments at the Olenyeksky branch containing the Lena signal represent the lower section of the third fluvial terrace in the Lena Delta (Schwamborn et al., 2002).

It can be inferred that snow patches in the Chekanovsky mountain ridges most likely acted as one of the source areas for the formation of the Ice Complex. Detrital grains may have been transported into the snow patches by eolian drift and/or surface water runoff. Later, the grains may have been carried away to the northern lowlands by meltwater runoff from the snow patch. 

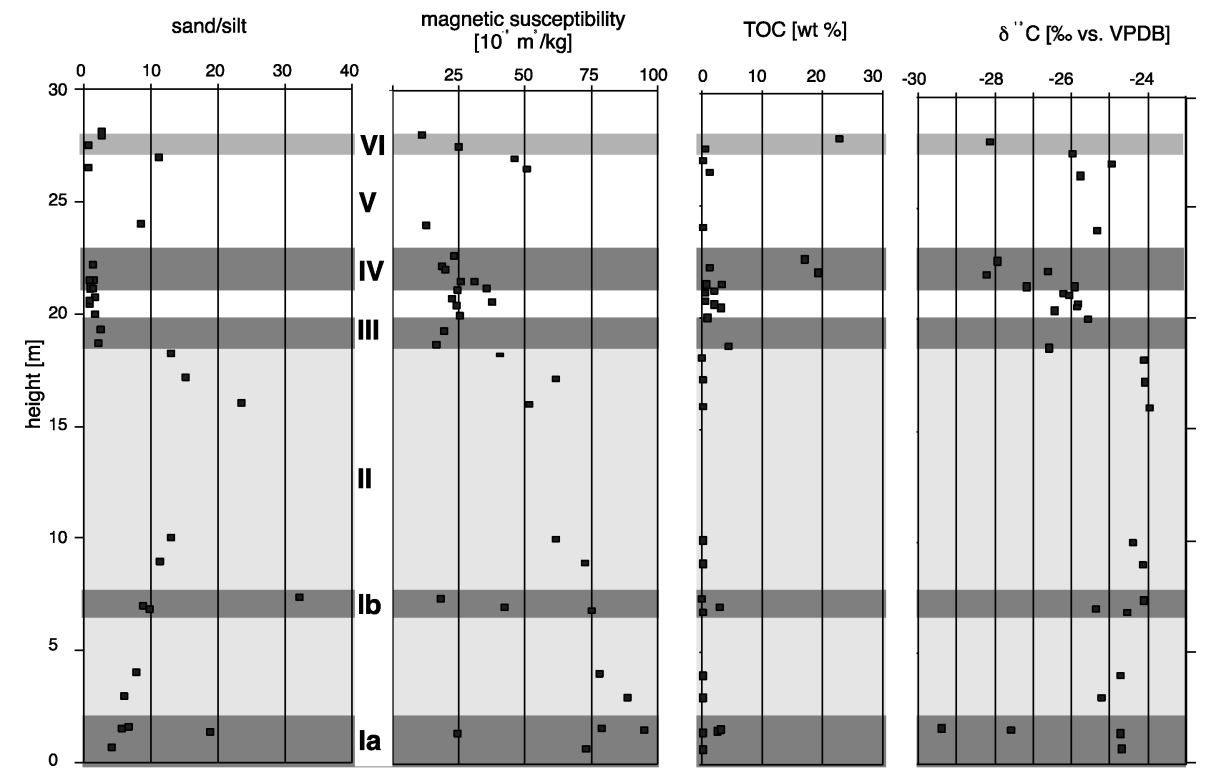

Fig. 12. Combination of sedimentological characteristics of several overlapping subprofiles of section A (Nagym, Ebe-Basyn-Sise Island): Ia = bedded peaty sand; $\mathrm{Ib}=$ plant-bearing sand; $\mathrm{II}=$ point bar sand; III = cryoturbated paleosol; IV = peat layer; V = Ice Complex unit; VI = Holocene cover and thermokarst deposits (see Fig. 8).

Data from overlapping subprofiles are combined in Figures 12 and 13. All sedimentological records clearly reflect strong facies change between the lower sand unit and the Ice Complex unit, as well as facial variations within these units.

The relationship between sand and silt contents varies slightly in the lowest part of the sandy unit, where alternating bedding with peaty sand layers is observed. The sand fraction predominates in higher parts of this unit and then decreases strongly at the Ice Complex boundary. The Ice Complex deposits are characterized by strong variations in the silt to sand ratio, reflecting changes in transport energy during the formation of the Ice Complex.

The argument of different sediment sources for both main units is also supported by mass-specific magnetic susceptibility data. High values of up to $50-100 \times 10^{-8} \mathrm{~m}^{3} /$ $\mathrm{kg}$ (SI) at section A, (Fig. 8) and 50-200 $\times 10^{-8} \mathrm{~m}^{3} / \mathrm{kg}$ at section B are characteristic for the lower sandy unit. The Ice Complex deposits of both sections have values predominantly lower than $50 \times 10^{-8} \mathrm{~m}^{3} / \mathrm{kg}$. Differences of about $20 \times 10^{-8} \mathrm{~m}^{3} / \mathrm{kg}$ were found between peaty paleosols, peat lenses, and intercalated sandy layers.

Layers with low TOC values characterize the lower sand unit. Only a few layers in the lower bedded peaty sand contain higher levels of organic carbon. The overlaying Ice Complex deposits contain more plant remains and respectively more organic carbon, particularly in peat lenses and inclusions. Similar variations were observed in Holocene deposits.

The stable carbon isotope composition of TOC shows clear differences between the lower sand unit and the Ice Complex unit. The sand layers of the lower unit have 

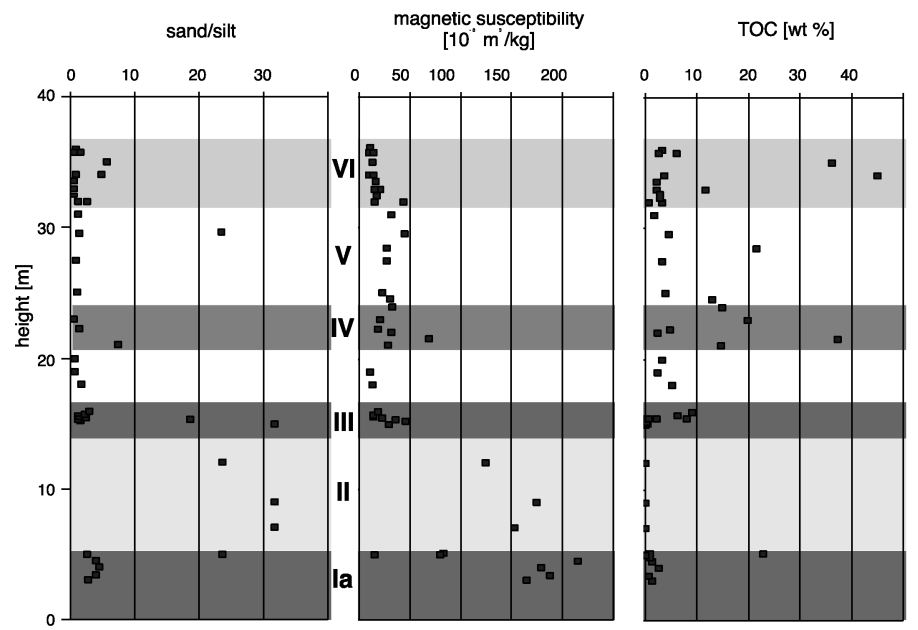

$\delta$ ' $\mathrm{C}[\% \circ$ vs. VPDB]

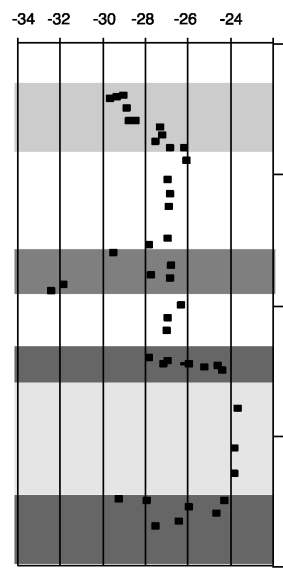

Fig. 13. Combination of sedimentological characteristics of several overlapping subprofiles of section B (Buor Khaya, Kurungnakh Island): Ia = bedded peaty sand; Ib = plant-bearing sand; $\mathrm{II}=$ point bar sand; III = cryoturbated paleosol; IV = peat layer; V = Ice Complex unit; VI = Holocene cover and thermokarst deposits (see Fig. 8).

the highest (heaviest) $\delta^{13} \mathrm{C}$ values of ca. $-23 \%$ in section B and ca. $-24 \%$ in section A. Plant detritus layers and single peat inclusions have lower values between $-26 \%$ and $-30 \%$, especially in the lowest bedded peaty sands of both sections. The paleosol horizon at the boundary between the main units is characterized by a strong decrease of carbon isotope values. In Ice Complex deposits these values decrease to $-26 \%$ o and $-28 \%$ in section $B$ and -25 to $-27 \%$ in section $A$. The lowest values of ca. -32 and $-33 \%$ in section B and of ca. $-28 \%$ in section A were measured in the peat horizon at the base of the Ice Complex unit as well as in Holocene peat. In section B, a trend to lower values is evident in Holocene deposits between 30 and $36 \mathrm{~m}$ height. The $\delta^{13} \mathrm{C}$ variations within the Ice Complex sequences are similar to those of the Bykovsky Peninsula (Schirrmeister et al., 2002b). The presence of numerous peaty paleosols seems to be responsible for the variation of $\delta^{13} \mathrm{C}$ values in these deposits. The explanation for the TOC $\delta^{13} \mathrm{C}$ variations is only preliminary due to the lack of substantial $\delta^{13} \mathrm{C}$ studies of organic matter in permafrost regions. The vegetation of Arctic ecosystems is mainly composed of C3 plants, which is reflected in the total range of $\delta^{13} \mathrm{C}$ values between -23 and $-33 \%$ (e.g., Clark and Fritz, 1997). C4 and CAM (Crassulaceae Acid Metabolism) plants do not play a major role in Arctic permafrost environments. CAM plants have no ecological advantages in polar regions without diurnal variations of brightness and darkness due to their diurnal alternation of the $\mathrm{CO}_{2}$ fixation. This alteration results in the isotope discrimination between brightness (e.g., C4 plants) and darkness (e.g., C3 plants). Therefore influences of C4 and CAM plants have to be excluded from the explanation of variations in our $\delta^{13} \mathrm{C}$ results.

The variation in $\delta^{13} \mathrm{C}$ values could be caused by changes in the overall composition of plant material. For instance, it could be linked to the amount of open water bodies occurring in the study region, and thus reflect the relationship of water plants 


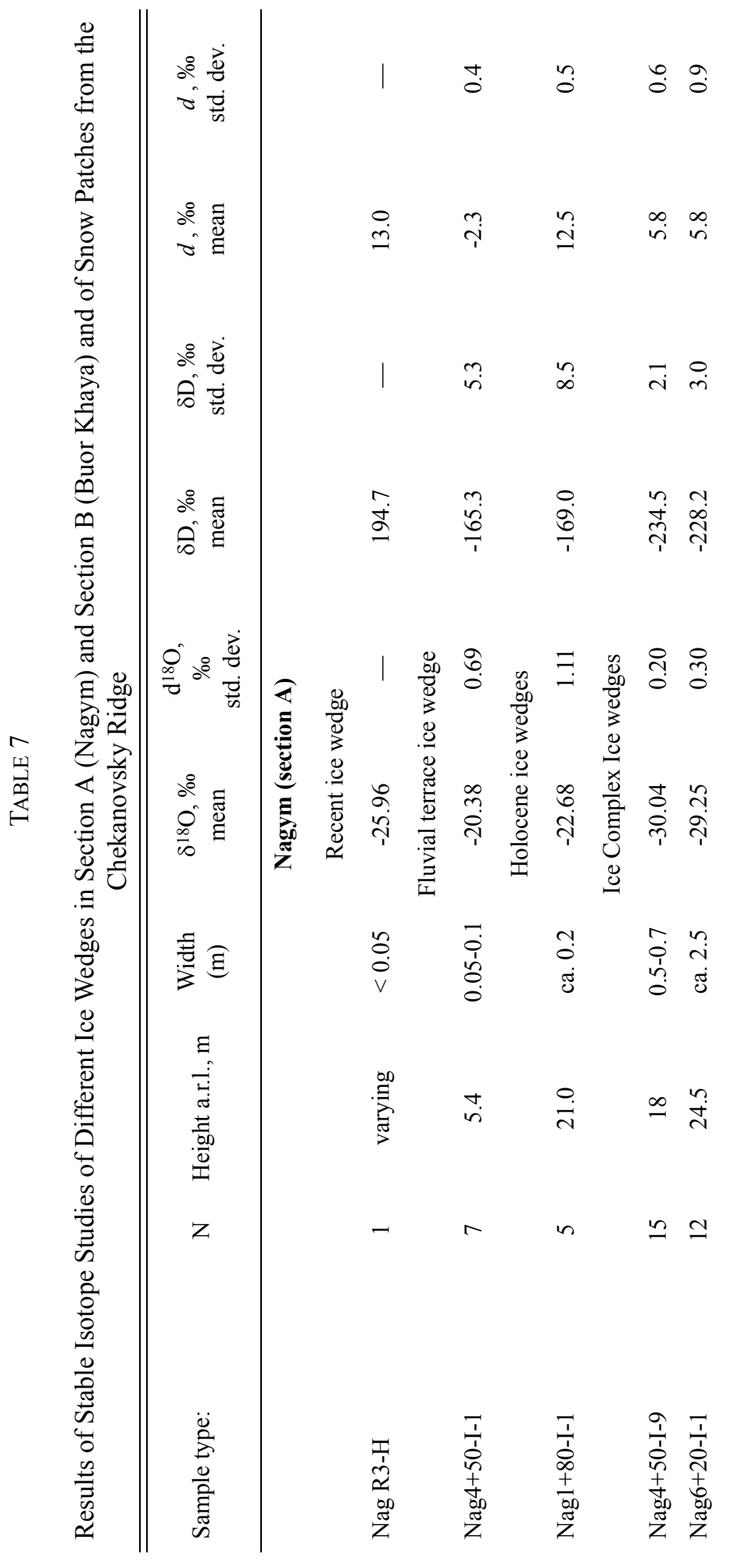




$$
\begin{aligned}
& \text { POLAR GEOGRAPHY }
\end{aligned}
$$

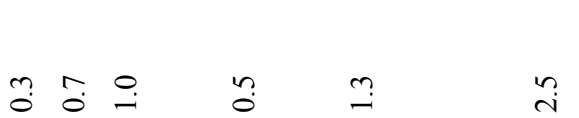

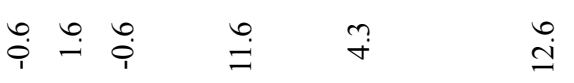

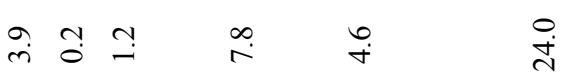

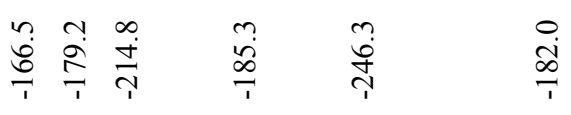

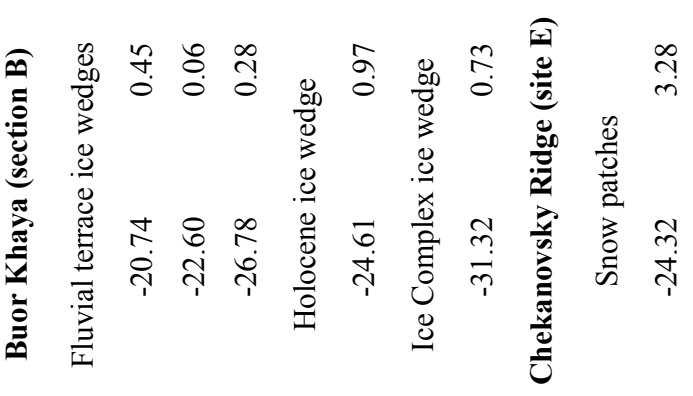

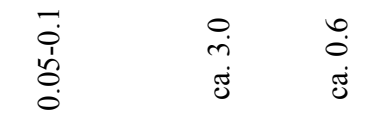

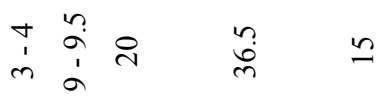

$$
\begin{aligned}
& \operatorname{sent}
\end{aligned}
$$

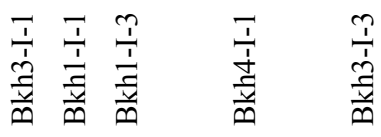


to land plants. Another reason could be linked to different isotopic fractionation during the carbon metabolism of the same plant associations. Environmental conditions including temperature, humidity, precipitation, and irradiation levels control both the vegetation composition and the carbon metabolism (Schliesser, 1995). According to Welker et al. (1995), the $\delta^{13} \mathrm{C}$ values of Cassiope tetragona cellulose nitrate from NyÅlesund at Svalbard vary between -27.9 and $-23.9 \%$ and seasonally up to $2.5 \%$, over a 25 -year period, due to variations in water supply (winter precipitation).

\section{Oxygen and Hydrogen Isotope Analyses of Ice Wedges and Snow Patches}

In geocryology, stable isotope analyses have been often used to differentiate types of ground ice (e.g., Vasil'chuk, 1992, Vasil'chuk and Kotlyakov, 2000; Vaikmäe, 1989). Ice wedges are considered particularly interesting for paleoclimate studies because during their formation (trickling of meltwater into frost cracks) the freezing process is rapid enough to avoid fractionation (Michel, 1982). Additionally, they represent a winter temperature signal because they are fed mainly by winter snow meltwater (MacKay, 1983; Vaikmäe, 1989).

In order to verify this assumption, two snow patches were sampled from the Chekanovsky Ridge near section A and compared to a recently formed ice wedge. The stable isotope composition of the recent ice wedge is similar to the mean isotope composition of the two snow patches in the Chekanovsky Ridge region, suggesting a genetic correlation between ice wedges and snow for the Lena Delta (Table 7). Similar results were also obtained for other profiles in the area, including one on the Bykovsky Peninsula, ca. $240 \mathrm{~km}$ or $140 \mathrm{~km}$, respectively, southeast of the studied sections $\mathrm{A}$ and $\mathrm{B}$. Several factors may influence the $\mathrm{O}$ and $\mathrm{H}$ isotopic composition of ice wedges, which are discussed in detail for the key site of the Bykovsky Peninsula (Meyer et al., 2002). These factors include seasonality of precipitation, fractionation processes (e.g., evaporation/sublimation of the snow cover and during the melting process), as well as varying moisture sources for different regions. Secondary processes such as migration of moisture within the permafrost may also play a role. Some of these effects have also been suggested by Wolfe et al. (2000) as important factors for the isotopic composition of Northern Eurasian climate archives.

Dansgaard (1964) defined the deuterium excess $\left(d=\delta \mathrm{D}-8 \delta^{18} \mathrm{O}\right)$, which is a valuable tool to identify sources of precipitation on a global scale, but also gives information about genetic correlations between different types of water or ice. The $d$ excess of snow samples and Holocene ice wedges (including the recent ice vein) are very similar at around $12 \%$, confirming the relationship between these ice wedges and the snow that is the main source for ice wedge growth. In addition, it suggests the persistence of similar ice wedge growth during the Holocene (even though the age of the sampled ice wedges is not exactly known). The Holocene ice wedges are distinguished from the greyish Ice Complex ice wedges by their smaller sizes, their white and milky ice color, and by their stable isotopic composition (Figs. 14A and 14B).

Stable isotope measurements of ice wedges in the sections A and B reveal the existence of three different types of ice wedges: Holocene ice wedges, Ice Complex ice wedges, and ice wedges of fluvial terraces (most likely of the paleo-Lena River). Holocene ice wedges were sampled in the section A (Nagym), where the sediment was dated to $4.82 \pm 0.04 \mathrm{ky}$ BP (Table 1), and in the section B (Buor Khaya), where 
A

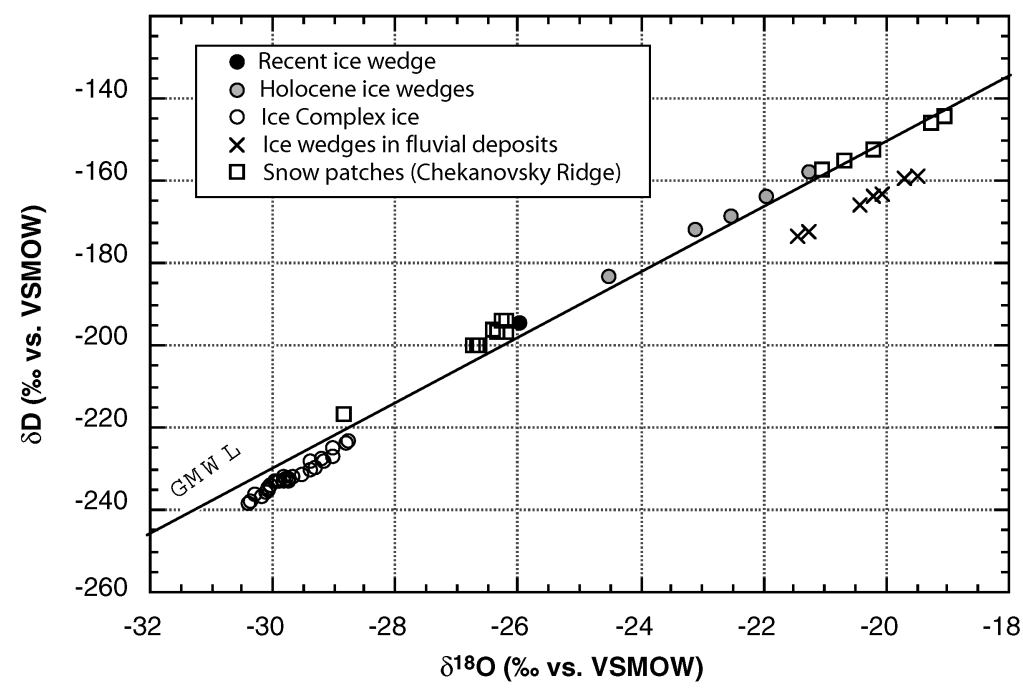

B

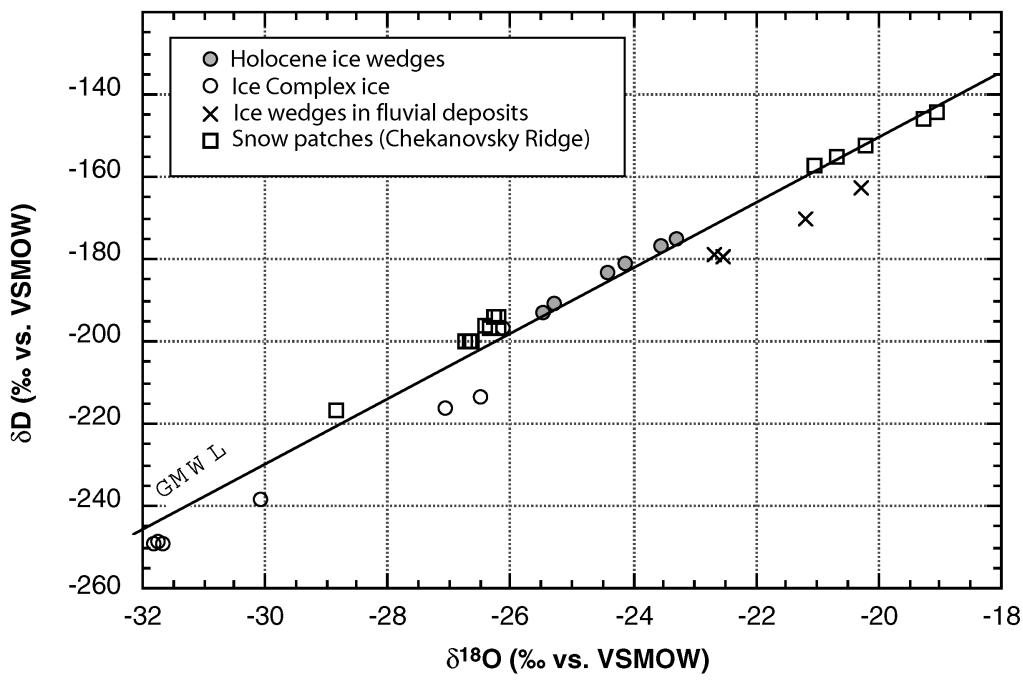

Fig. 14. Oxygen and hydrogen stable isotopes of ice wedges from two sections (A and B) of the Olenyeksky distributary and of snow patches in the Chekanovsky Ridge. A. $\delta^{18} \mathrm{O}-\delta$ d diagram for section A (Nagym). B. $\delta^{18} \mathrm{O}-\delta$ d diagram for section B (Buor Khaya).

adjacent sediments were radiocarbon dated between $7.59 \pm 0.05$ and $8.62 \pm 0.07 \mathrm{ky}$ BP (Table 3). Samples from these ice wedges, as well as a recent ice wedge in section A (Nagym), show a relatively heavy (positive) isotopic composition between -169 and $-195 \%$ for $\delta \mathrm{D}$ and between -22.7 and $-26.0 \%$ for $\delta^{18} \mathrm{O}$ and a relatively high $d$ excess (Table 7). The sampled ice wedges of the Ice Complex are located within 
deposits dated from $>45 \mathrm{ky}$ to about $44 \mathrm{ky} \mathrm{BP}$. These ice wedges are characterized by a lighter (more negative) isotopic composition varying around $\delta \mathrm{D}=-230 \%$ and $\delta^{18} \mathrm{O}=-30 \%$, and a $d$ excess varying around $5 \%$ for both Lena Delta locations. These results point to warmer winter temperatures during the Holocene compared to the time of Ice Complex ice wedge formation during the Late Pleistocene. Similar results have been obtained on the Bykovsky Peninsula, where a shift in the $d$ excess between Holocene and Pleistocene ice wedges was reported (Meyer et al., 2002). The $d$ excess on the Bykovsky Peninsula was interpreted as an indicator of the conditions in the moisture source regions where the precipitation originates (e.g., Jouzel et al., 1982). Consequently, a change of the moisture source region was postulated as a possible reason for different $d$ excess values of Holocene and Ice Complex ice wedges (Meyer et al., 2002).

The isotopic composition of ice wedges in the fluvial deposits underlying the Ice Complex varies between $-20.5 \%$ and $23 \%$ for $\delta^{18} \mathrm{O}$ and around $-170 \%$ for $\delta \mathrm{D}$. The $d$ excess values are the lowest of the studied ice wedges (around $0 \%$ ). The period of deposition of this sediment unit was dated by ${ }^{14} \mathrm{C}$ AMS and IRSL methods between 50 and $90 \mathrm{ka}$. Consequently, ice wedges buried in these sediments (from 0 to 15 meters above river level, Fig. 3) are within this age range and are the oldest in the studied section. Only one ice wedge (BKh1-I3) is associated with the overlying Ice Complex and penetrates into the sandy unit from the top (Fig. 5B). As this period is not known as having been particularly warm, it can be assumed that the heavy isotopic composition of ice wedges in fluvial deposits was not solely influenced by climatic variations. Most likely these ice wedges were fed by a different source. For example, water entering frost cracks from river flooding would give no winter signal, but instead the isotopic composition of the river itself, which additionally may be subject to evaporation. An event of this nature could explain both the low $d$ excess and the heavy oxygen and hydrogen isotopic composition. The fact that the Lena River presently possesses an isotopic composition of $-19.4 \%$ for $\delta^{18} \mathrm{O}$ according to Brezgunov et al. (1998) and of $-20.5 \%$ for $\delta^{18} \mathrm{O},-156 \%$ for $\delta \mathrm{D}$, and $8 \%$ for $d$ excess $(N=17)$ according to Rachold (unpubl. data), which is very close to that measured in these ice wedge types, supports the assumption of a river water source. Since these particular ice wedges evidently did not form from winter snow, their stable isotopic composition cannot be used for the reconstruction of paleo-winter temperatures.

\section{Results of Paleoenvironmental Studies of Section B, Buor Khaya}

Pollen analysis. Six paleoenvironmental periods (zones) can be distinguished by pollen analysis (Fig. 15). Zone I, corresponding to the sandy unit, is characterized by large amounts of reworked indeterminable (mineralized and poorly preserved) ancient Pinaceae and the presence of Pre-Quaternary spores and pollen (Corylus and Juglans). Pollen from other tree species (mostly Picea, Pinus, and Abies) are probably reworked as well. Reworked pollen and spores indicate the denudation of PreQuaternary deposits confirming the fluvial character of the lowest deposits. The high contents of reworked pollen and very low pollen concentration may indicate scarce vegetation and/or a high accumulation rate around the site. According to the pollen spectra, sparse grass and sedge communities dominated the vegetation $>57 \mathrm{ky}$ BP. Similar pollen spectra, radiocarbon dated ca. $60-53 \mathrm{ky}$ BP, were also found on the 


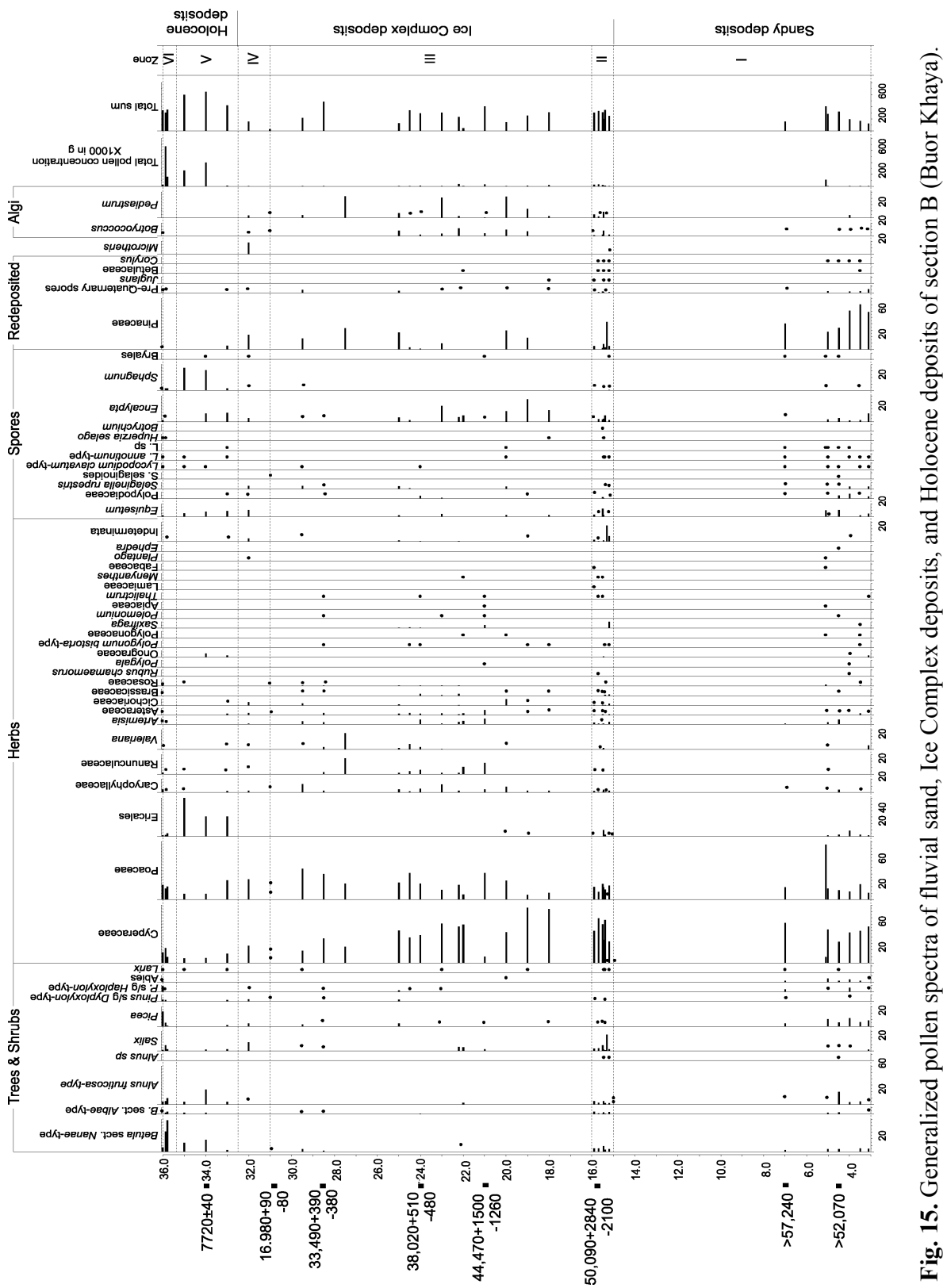


Bykovsky Peninsula, located $140 \mathrm{~km}$ to the east of Buor-Khaya (Andreev et al., 2002; Schirrmeister et al., 2002b). The respective climate was relatively cold and dry.

Higher pollen concentrations with dominance of Cyperaceae and Poaceae pollen, along with Caryophyllaceae, Ranunculaceae, Asteraceae, Artemisia, and Ericales are typical for the sediments dated to ca. $50 \mathrm{ky} \mathrm{BP} \mathrm{(zone} \mathrm{II} \mathrm{of} \mathrm{Fig.} \mathrm{15).} \mathrm{These} \mathrm{deposits} \mathrm{at}$ the bottom of the Ice Complex unit represent the change to typical foreland plain or floodplain habitats. Some shrub taxa pollen (Salix, Betula sect. Nanae, and Alnus fruticosa) and Ericales are also present. This pollen spectrum corresponds well with those from the beginning of the Kargin Interstadial (Kind, 1974; Isaeva, 1984; Anderson and Lozhkin, 2001). These spectra indicate that open tundra-like associations dominated the area, although shrubby tundra communities were probably present on the landscape as well. A relatively high content of Pediastrum and Botryococcus colonies in the sediments indicates the existence of shallow water bodies (e.g., pools in the center ice wedge polygons). The climate was relatively wet and warm.

The dominance of Poaceae and Cyperaceae pollen with some Caryophyllaceae, Ranunculaceae, Asteraceae, Artemisia, and Saxifraga and a relatively high pollen concentration is typical for the Ice Complex sediments dated between 50 and $33.5 \mathrm{ky}$ BP (zone III of Fig. 15). This spectrum corresponds well with those from the Kargin Interstadial (Kind, 1974; Isaeva, 1984; Anderson and Lozhkin, 2001). The pollen spectra indicate that open steppe-like and tundra-like associations dominated the area. A relatively high content of Pediastrum and Botryococcus colonies and Cyperaceae in the sediments dated ca. 47-38 ky BP may indicate a relatively wet climate during this interval. A similar environment was reconstructed for this time on the Bykovsky Peninsula (Andreev et al., 2002; Schirrmeister et al., 2002b).

Very low pollen concentrations in the uppermost part of the Ice Complex (zone IV of Fig. 15) may indicate scarce vegetation around the site or more likely low pollen production during the Sartan stadial, particularly around the Last Glacial Maximum (a sample with extremely low pollen content was radiocarbon dated to $16.98+$ $0.09 /-0.08$ ky BP). The pollen spectra deposited during the Sartan also contain reworked indeterminable Pinaceae pollen grains, which may reflect a low pollen productivity of the local plant communities and/or a sparse vegetation cover. It can be assumed that scarce steppe-like Poaceae communities with some Caryophyllaceae, Asteraceae, and Cichoriaceae covered the study area. The peaks of Cichoriaceae, Equisetum, Encalypta, and Selaginella rupestris contents indicate that disturbed, exposed soils were common in the area. The climate was extremely cold and dry.

A dramatic increase in Ericales pollen content and a small increase in Alnus fruticosa and Betula nana pollen at the beginning of zone V may indicate early Holocene or Allerød warming. A pollen spectrum dated to ca. $7.7 \mathrm{ky}$ BP is characterized by a dramatic increase in the content of Alnus fruticosa and Betula nana pollen and Sphagnum spores, as well as of total pollen and spore concentrations. These changes suggest that shrubby tundra was widely distributed at the Buor-Khaya site during that time. The domination of Sphagnum (among spores) indicates a paludification of the local shrubby tundra. The high shrub pollen percentages in the spectrum indicate that the climate conditions were most favorable for vegetation during the Early Holocene. A relatively high amount of Encalypta spores reflects the presence of disturbed soils caused by solifluction and thermal erosion processes. The data are in good agreement 


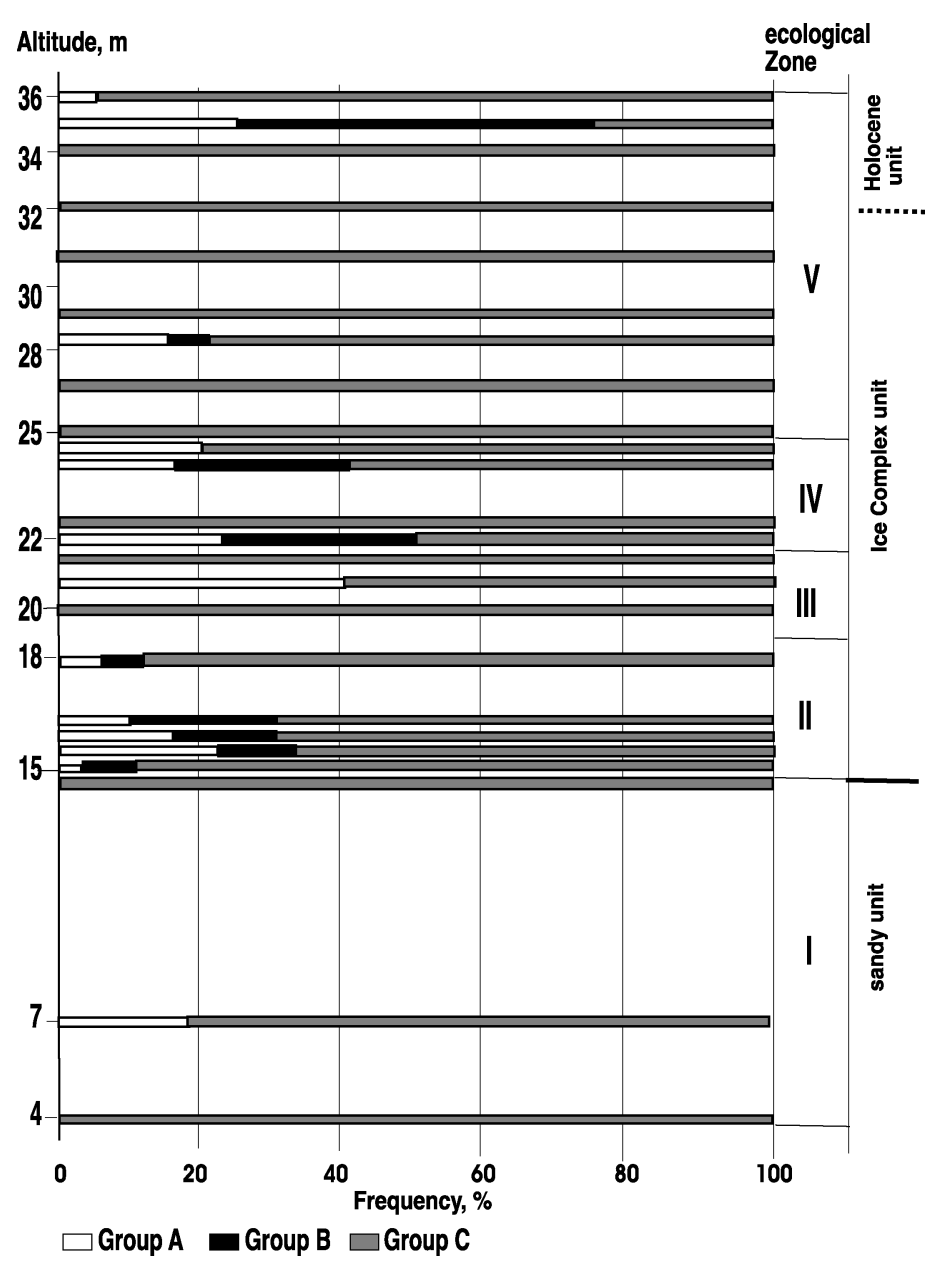

Fig. 16. Results of rhizopod analysis from section A (Buor Khaya): Group A = hygrophilous and hydrophilous species; Group B = sphagnophilous species; Group $\mathrm{C}=$ soil and eubiontic species.

with other early Holocene pollen records from the region (Pisaric et al., 2001; Andreev et al., 2004, in press; Schirrmeister et al., 2002b).

The pollen spectra from the upper part of the section (zone VI) are characterized by a decrease in Alnus fruticosa and Ericales pollen and Sphagnum spores, while the contents of long-distance pollen (Picea, Pinus) increase. The uppermost spectrum, dominated by Betula sect. Nanae, Poaceae, and Cyperaceae pollen, reflects the modern vegetation cover.

Testate amoebae (Protozoa: Testacea). Five paleoenvironmental periods (zones) can be distinguished by rhizopod analyses (Fig. 16). The oldest low-diversity testate amoebae were found in fluvial sandy sediments between 4 and $15.3 \mathrm{~m}$ above the river (zone I of Fig. 16). Testate shells are absent in many samples, probably reflecting the fluvial (reworked) character of these sands and/or high sedimentation rates. 
Environmental conditions were unfavorable for rhizopods and/or for their shell preservation. A great number of remains were found only in one sample, radiocarbon dated to $>57.24 \mathrm{ky}$ BP. The presence of nine species from hydrophilous and euribiont groups (Difflugia and Centropyxis species) indicate hydromorphic conditions at the site, perhaps in a river point bar pool.

Samples from 15.4 to $18 \mathrm{~m}$ above the river at the base of the Ice Complex unit contain another Testaceae paleocoenose (zone II of Fig. 16). The species diversity is very high and all main ecological groups are present: hydrophilous (Difflugia genus), soil (Centropyxis, Cyclopyxis and Plagiopyxis genera), wetland (Nebela, Heleopera genera), as well as euribiont species. A number of samples contain sphagnophilous species from the genus Argynnia. This species has previously only been found in Northern Eurasia in samples from the Bykovsky Peninsula, radiocarbon dated to ca. 45.3-43 ky BP (Schirrmeister et al., 2002b; Bobrov et al., 2003). Remains of Centropyxis plagiostoma (calciphilous) are present in all samples, indicating the mesotrophic character of nutrition during this period. Environmental conditions in a foreland accumulation plain with polygonal tundra habitats were relatively favorable for rhizopods.

Samples from 19-21.5 $\mathrm{m}$ above the river contain a few Testaceae remains (zone III of Fig. 16). The sample, radiocarbon dated to $44.47+1.5 /-1.26$ ky BP (Drepanocladus-Equisetum peat), contains six species from the hydrophilous (Arcella and Difflugia) and euribiont groups. This habitat can be characterized as a wet, but non-oligotrophic environment. Generally, environmental conditions were unfavorable for rhizopods during this interval.

Testaceae remains from 22 to $24.5 \mathrm{~m}$ above the river in the middle part of the Ice Complex unit, radiocarbon dated to $43-38$ ky BP (zone IV of Fig. 15), indicate that a mesotrophic wetland environment dominated during this time period. An exotic species, sphagnophilous Argynnia sp. is also present. The sample from $22.2 \mathrm{~m}$ above the river is distinguished by the presence of 17 soil and euribiont species, indicating a humus-accumulative horizon of slightly acidic soil. Generally, the soil conditions were warmer and wetter than during the previous interval, perhaps because of more stable surface conditions.

According to results of rhizopod analyses, the deposits from $25 \mathrm{~m}$ to the modern surface (zone V of Fig. 16) are mainly humus-accumulative horizons of paleosols, which were formed in a polygonal tundra landscape. The samples are characterized by low species diversity; in some samples no rhizopods were found at all. The Testaceae remains belong mostly to soil and euribiont species. The only sample with hydrophilous Difflugia species, radiocarbon dated to $33.4+0.39 /-0.38 \mathrm{ky} \mathrm{BP}$, indicates hydromorphic conditions at the site at that time. Remains of calciphilous Centropyxis plagiostoma are present only in the samples from 27.5 to $29.5 \mathrm{~m}$ above the river, indicating that soil formation occurred in calcium-rich deposits.

Only soil and euribiont species are found in the samples from 29.5 to $34.0 \mathrm{~m}$, reflecting a very dry climate during the Late Glacial period (a sample from $31.0 \mathrm{~m}$ altitude is radiocarbon dated to $16.98+0.09 /-0.08 \mathrm{ky} \mathrm{BP}$ ). After $7.7 \mathrm{ky} \mathrm{BP}$, the local soil environment was much wetter, as indicated by the presence of hydrophilous and sphagnophilous species.

Generally, the species diversity and ecological groups of rhizopods in the first, third, and fifth zones (Fig. 15) were close to those of the A horizon of the modern soil 
at the site. However, the soil conditions were drier than those of today. The absence of Testaceae remains in some samples in the lower part of the profile reflects fluvial conditions without soil formation, when reworked material was deposited at the site.

\section{STRATIGRAPHY AND FACIES INTERPRETATION}

The four studied sections situated in an area of about $200 \times 200 \mathrm{~km}$ in the western Lena Delta are composed of both sand and Ice Complex units as described above. Similar sequences are exposed in numerous locations along the Lena River branches in the western Lena Delta.

Five major environmental periods were distinguished on the basis of the pollen and rhizopod analysis of section B (Buor Khaya, Kurungnakh Island) (Table 8). The oldest period $\left(>57{ }^{14} \mathrm{C}\right.$ ky BP) is characterized by scarce vegetation, reworked sediments and/or high sedimentation rates, hydromorphic soil conditions, and a cold, dry climate. These conditions characterize the formation of the lower sand unit at this site dated by IRSL between $88 \pm 14 \mathrm{ka}$ and $65 \pm 8 \mathrm{ka}$.

The main part of the Ice Complex deposits was accumulated, during the period radiocarbon dated between ca. $50+3 /-2 \mathrm{ky} \mathrm{BP}$ and $33 \pm 0.4 \mathrm{ky} \mathrm{BP}$, corresponding to the Kargin Interstadial (Kind, 1974; Isaeva, 1984; Anderson and Lozhkin, 2001). This time period was characterized by tundra-like vegetation, and a relatively warm and wet climate. Pollen and rhizopod studies indicate that the most favorable, wettest, and warmest conditions during the Kargin interstadial existed between ca. 44 and $38 \mathrm{ky}$ BP.

The following stage corresponds to the extreme cold and dry Sartan stadial (Kind, 1974; Isaeva, 1984; Anderson and Lozhkin, 2001). Scarce steppe-like vegetation covered the study area. The soil conditions were dry. The formation of the Ice Complex was terminated at the end of the Sartan stadial (about $13 \mathrm{ky} \mathrm{BP).} \mathrm{The} \mathrm{Late} \mathrm{Pleis-}$ tocene/Early Holocene transition is indicated by a dramatic increase of shrub pollen in the spectra, reflecting alder-dwarf birch tundra with wetter soil conditions that dominated the area during the Early Holocene.

The sediments of both the sandy and Ice Complex units are of different origin and from different source areas. The sandy units were formed between ca. $100 \mathrm{ka}$ and $50 \mathrm{ka}$, and the Ice Complex between ca. $50 \mathrm{ky}$ BP and $10 \mathrm{ky} \mathrm{BP}$. The accumulation of the sandy unit took place in shallow water with small current energy, perhaps in a braided river system with large seasonal variation in discharge (periglacial runoff system). The occurrence of ice wedges within these deposits indicates frost cracking. Thus, the sandy surface episodically was dry (also shown by vegetation types). The clastic material is assumed to be composed of Lena River sands. The oxygen and hydrogen isotope data of ice wedges formed in these deposits also point to a fluvial origin of the ice wedges. The origin of the lower sand unit was possibly similar to glacial meltwater flood deposits in Central Yakutia. There are a few lithological similarities between the Marinsky Suite of the fourth terrace (Grinenko et al., 1995) of the Lena River (Bestyakhskaya Terrace) near the town Yakutsk and the studied sandy deposits of the western Lena Delta. These sands accumulated on the bottom and sides of large meltwater streams when large, extended areas of the periglacial plain were flooded in the spring. 


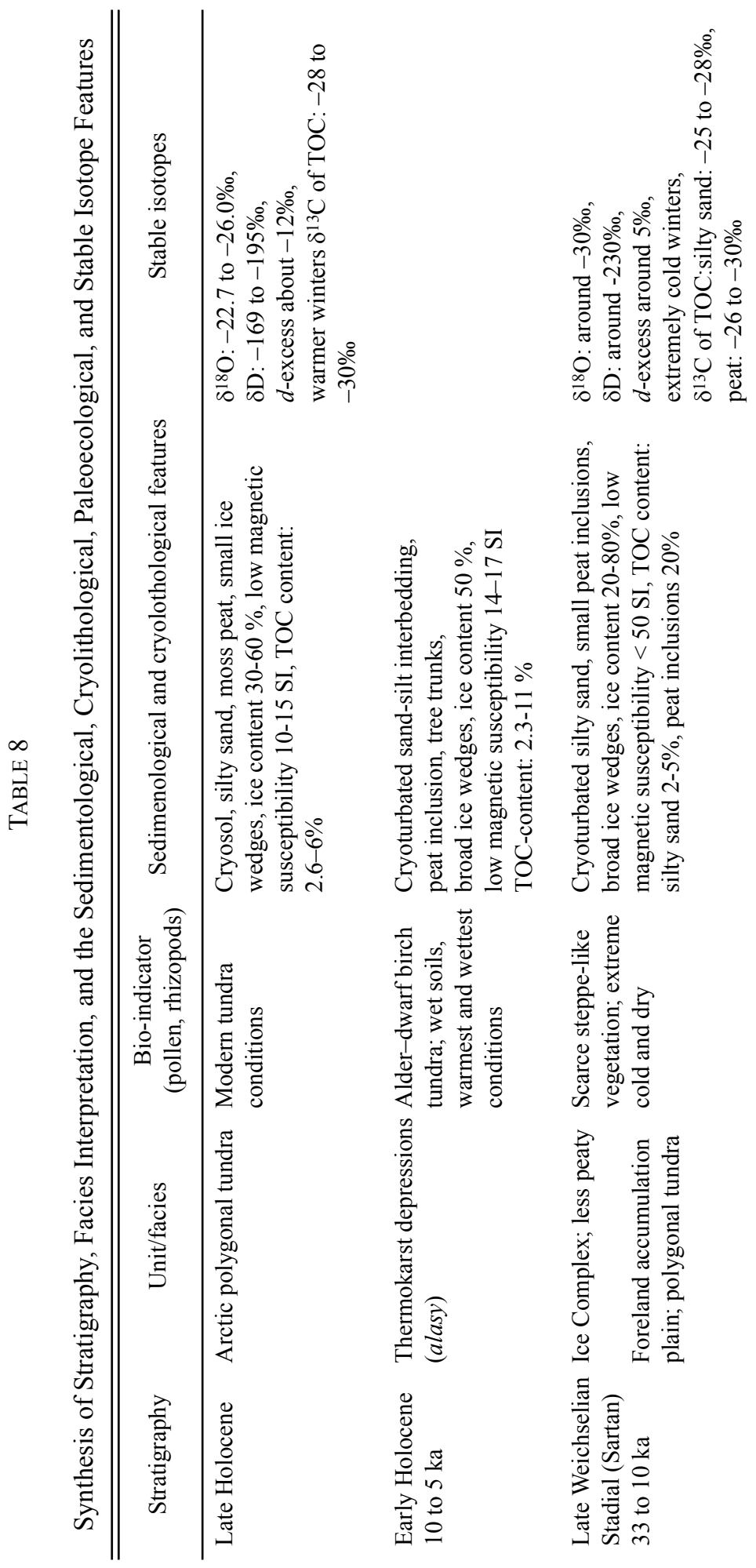




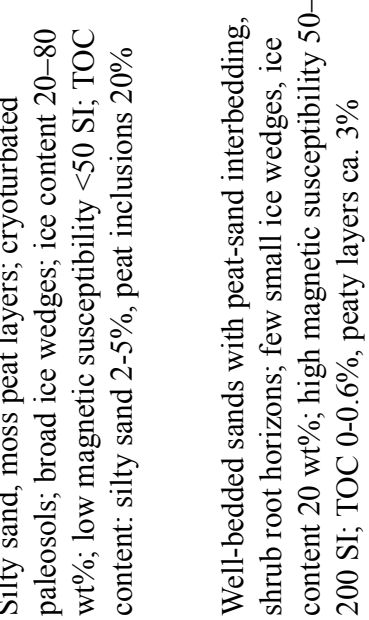

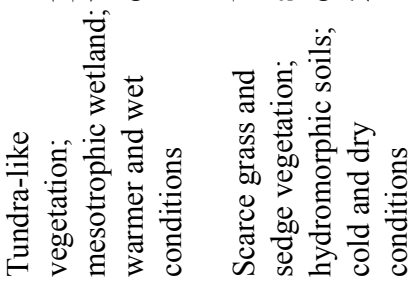

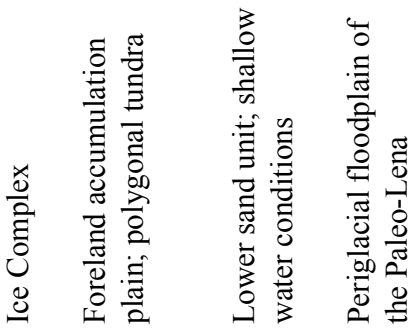

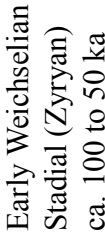

กิ

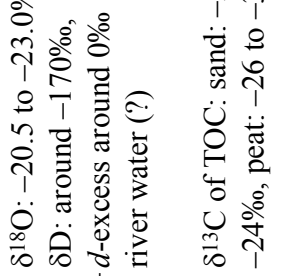

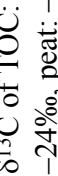

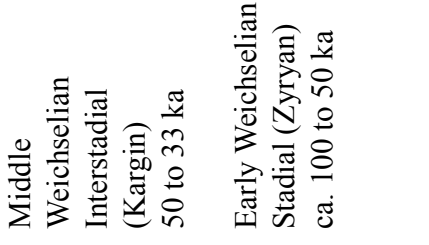


Galabala (1987) considered the lower sand unit as a fluvial Paleo-Lena River formation of an inner-continental delta, and Kunitsky (1989) assigned these sediments to the meltwater flood deposits of the periglacial facies. We interpret this unit as a floodplain facies of the Early Weichselian Lena River. At this time the major Lena River branch was oriented to the north and most likely the Lena Delta extended farther north as well. The wide distribution of the same fine-bedded sands along the Olenyeksky distributary, as well as along the river branches of the western Lena delta south of Arga Island, confirm this conclusion. These sands accumulated in a shallow aquatic environment with some facial variations in transport energy and direction.

The reason for the formation of such a large floodplain was perhaps tectonic, suggesting that large parts of tectonic blocks north of Chekanovsky Ridge subsided and a large valley was formed. A similar situation is noted in the broad upper Lena River valley near Yakutsk. Therefore, the lower sand unit seems to be a deposit of the PaleoLena, which might have been accumulated during seasonal meltwater floods before the Lena River broke through the northern Verkhoyansky Range separating it into the Chekanovsky and Kharaulakh ridges, which, according to Lungersgauzen (1961), could have only happened during the Late Pleistocene $\left(\mathrm{Q}_{\mathrm{III}}\right)$.

Eventually, the hydrological regime of the studied region changed suddenly, forced by an assumed strong tectonic event and/or a rapid climate change. The sedimentation of sandy floodplain deposits ended and a distinct paleocryosol was formed in the sandy unit during a period of stable terrestrial surface conditions. The fact that the floodplain was no longer episodically flooded by the Lena River is supported by the stable isotope data of ice wedges.

The formation of the Ice Complex deposits began after a climatic deterioration. The Ice Complex unit discordantly covers the sandy deposits. The Ice Complex deposits at the Olenyeksky distributary are similar to those of the Bykovsky Peninsula (Schirrmeister et al., 2002b). They were probably formed by various accumulation processes connected with nival processes at the Chekanovsky Ridge (Fig. 17). The sedimentation plain was formed in front of the Chekanovsky Ridge during the Late Pleistocene, when the Ice Complex deposits covered the large area north of the Chekanovsky Ridge. These so-called "extranivitiy" sediments were influenced by nival conditions according to Kunitsky (1989) and Kunitsky et al. (2002), but accumulated at distances of about 30 to $50 \mathrm{~km}$ from the source area (Chekanovsky Ridge) where the nival processes occurred. In contrast to the Bykovsky Peninsula, Ice Complex deposits-were formed closer to the mountains and therefore the grain size distribution is significantly coarser. Frost cracking was frequent, as shown by huge ice wedges, thus suggesting subaerial conditions and a thin snow cover.

The transport of clastic and organic matter took place through many discontinuous rivulets and brooks fed by snow-patch meltwater or by sheet flow when parts of the sedimentation plain were flooded by meltwater (Fig. 17). These deposits, supersaturated with water, were frozen in winter and gradually were included into the permafrost subsurface as soon as a sufficient amount of newly formed sediment covered the frozen deposits. Soils and peat formed during more stable surface conditions when meltwater followed other runoff paths, especially during the Kargin Interstadial period. Large systems of ice wedge polygons were formed during this time.

The early Holocene sea level rise resulted in the shifting of the Lena Delta back to the south and a splitting into the modern main river branches (distributaries). The Ice 


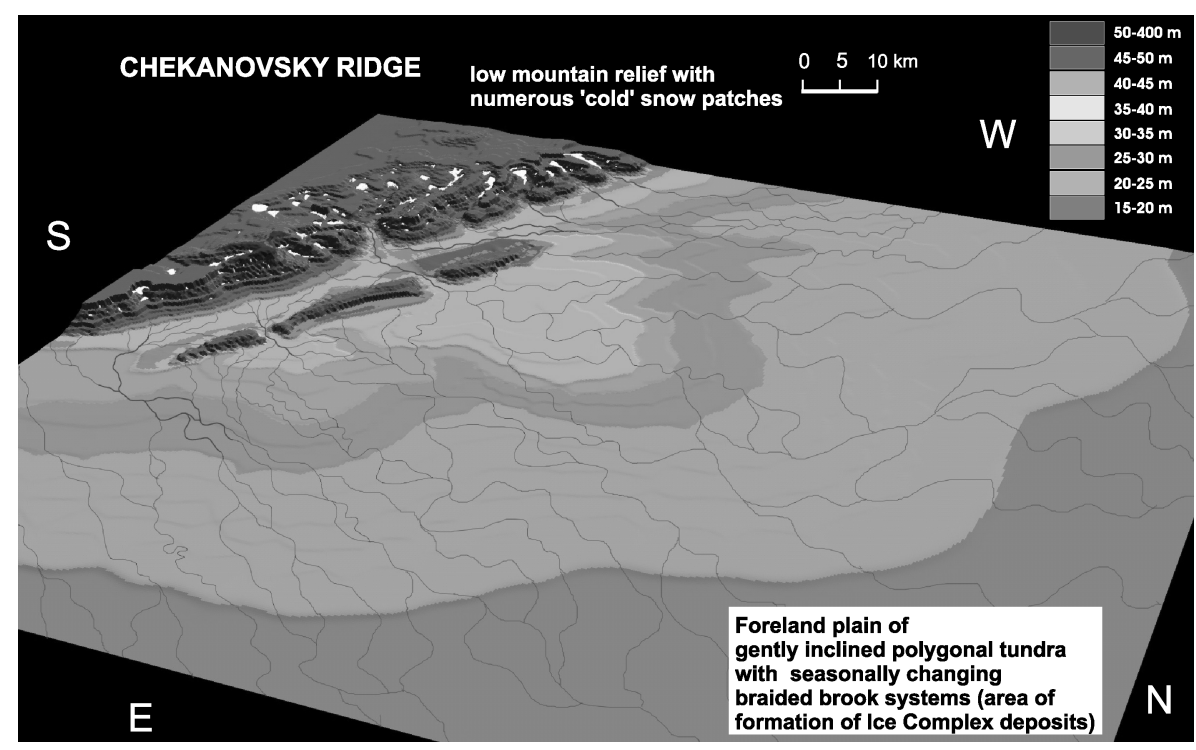

Fig. 17. Assumed foreland plain in front of the Chekanovsky Ridge as an area of Ice Complex formation (after Kunitsky et al., 2002).

Complex deposits mainly occur as relicts in the western Lena Delta because of Holocene thermokarst and thermoerosion processes and because of the fluvial erosion of the Lena River branches.

The widely distributed sandy deposits, found on the northern border of ArgaMuora-Sise Island, are correlated by Gabala (1987) with the studied sandy unit exposed at the Olenyeksky branch. According to Galabala (1987), the sandy Muorinsky Suite $\left(\mathrm{Q}_{\mathrm{II}}{ }^{1}-\mathrm{Q}_{\mathrm{III}}{ }^{1}\right)$ is totally covered by sands of the Turakhsky Suite $\left(\mathrm{Q}_{\mathrm{III}}{ }^{2}\right)$ on Arga-Muora-Sise Island. New age determinations show that the outcropped sandy deposits there at a depth of about 1 to $4 \mathrm{~m}$ were formed between 14.5 and $10.9 \mathrm{ky}$ BP (Krbetschek et al., 2002; Schwamborn et al., 2002).

\section{CONCLUSION}

Deposits from the Early Weichselian period of about $100 \mathrm{ka}$ BP up to the Holocene were investigated at the Olenyeksky distributary and other branches of the western Lena Delta. The sharp boundary between the widely distributed sequences of fluvial sands deposited under shallow-water conditions of point bars and the overlying Ice Complex deposits reflect strong environmental changes in this area during the Late Pleistocene. Changes of hydrological (geomorphological) conditions were probably caused by tectonic events as well as climate change. The mineral sources of the two units are clearly different. Whereas the fluvial sand unit consists of heavy mineral associations similar to those of recent Lena River deposits, the heavy mineral association of the Ice Complex deposits is similar to sediments of the adjacent Chekanovsky Ridge. The strong connection between the Ice Complex formation and the nearby mountain areas is typical at least for the Laptev Sea coastal lowland. Increased nival 
processes in the mountains during the Late Pleistocene are considered to be a driving force for the formation of the Ice Complex unit.

The stable isotopic composition of ice wedges in the Nagym and Buor Khaya sections may be used to distinguish the Holocene ice wedges, Ice Complex ice wedges, and ice wedges of fluvial terraces (which have been formed most likely by flooding of the Paleo-Lena River). The latter ice wedges are therefore not useful for paleoclimate reconstructions.

The paleoecological information obtained from pollen and rhizopod studies of the lower sand unit support the fluvial genesis of the sediments. Bioindicators from the late Pleistocene Ice Complex and Holocene deposits reflect the environmental changes during the Kargin interstadial, the Sartan stadial, and the Holocene. The strong change of climate conditions is also reported by the explicit differences of stable isotope values of the Late Pleistocene and Holocene ice wedges.

\section{LITERATURE}

Are, F. E. and E. Reimnitz. "An overview of the Lena River Delta setting: Geology, tectonics, geomorphology, and hydrology," Journal of Coastal Research, Vol. 16, No. 4, 2000, pp. 1083-1093.

Anderson, P. M. and A. V. Lozhkin. "The Stage 3 interstadial complex (Karginskii/ Middle Wisconsinan interval) of Beringia: Variations in paleoenvironments and implications for paleoclimatic interpretations," Quaternary Science Reviews, Vol. 20, Nos. 1-3, 2001, pp. 93-125.

Andreev, A. A., L. Schirrmeister, Ch. Siegert, A. A. Bobrov, D. Demske, M. Seiffert, and H.-W. Hubberten. "Paleoenvironmental changes in northeastern Siberia during the Upper Quaternary-Evidence from pollen records of the Bykovsky Peninsula," Polarforschung, Vol. 70, 2002, pp. 13-26.

Andreev, A. A., P.E. Tarasov, G. Schwamborn, B. P. Ilyashuk, E. A. Ilyashuk, A. A. Bobrov, V. A. Klimanov, V. Rachold, and H.-W. Hubberten. "Holocene paleoenvironmental records from Nikolay Lake, Lena River Delta, Arctic Russia," Paleogeography, Paleoclimatology, Paleoecology, 2004, in press.

Berglund, B. E. and M. Ralska-Jasiveczowa. "Pollen analysis and pollen diagrams," in: B. E. Berglund, ed., Handbook of Holocene Paleoecology and Paleohydrology. New York, NY: Interscience, 1986, pp. 455-484.

Bobrov, A. A., A. A. Andreev, L. Schirrmeister, and C. Siegert. "Testate amoebae (Protozoa: Testacea) as bioindicators in the Late Quaternary deposits of the Bykovsky Peninsula, Laptev Sea, Russia," Paleogeography, Paleoclimatology, Paleoecology, Vol 30, No. 2, 2003, pp. 191-206.

Boenigk, W. Schwermineralanalyse. Stuttgart, Germany: Ferdinand Enke Publishers, 1983, $158 \mathrm{pp}$.

Brezgunov, B. S., A. D. Yesikov, V. I. Ferronsky, and L. V. Sal'nova. "Spatialtemporal variations of oxygen isotope composition in precipitation and river water of Northern Eurasia and their relation to temperature changes," Vodnyye Resursy, Vol. 25, No. 1, 1998, pp. 99-104 (in Russian).

Clark, I. and P. Fritz. Environmental Isotopes in Hydrology. New York, NY: Lewis Publishers, 1997, 328 pp.

Dansgaard, W. "Stable isotopes in precipitation," Tellus, Vol. 16, 1964, pp. 436-458. 
Elias, S. A. and J. Brigham-Grette. "Beringian paleoenvironments-Festschrift in honor of D. M. Hopkins," Quaternary Science Reviews, Vol. 20, No. 1-3, 2001, pp. 1-574.

Faegri, K. and J. Iversen. Textbook of Pollen Analysis, 4th ed. (revised by K. Faegri, P. E. Kaland, and K. Krzyinski). Chichester, UK: Wiley, 1989, 200 p.

French, H. M. The Periglacial Environment, 2nd ed. Harlow, UK: Longman, 1996, $341 \mathrm{p}$.

Galabala, R. O. "New data on the Lena Delta structure," in: V. P. Pokhilainen, ed., Chetvertichnyy period v Severo-Vostochnoy Azii (Quaternary of North East Asia). Magadan, Russia: SVKNII DVO AN SSSR, 1987, pp. 152-172 (in Russian).

Geyh, M. A. "Precise 'isochron'-derived detritus-corrected U/Th dates." Paper presented at the 16th Radiocarbon Conference, Groningen, Netherlands, June 1994.

Grigoriev, M. N. Cryomorphogenesis of the Lena River Mouth Area. Yakutsk, Russia: SB RAS, 1993, 176 p. (in Russian).

Grigoriev, N. F. Perennially Frozen Ground of the Yakutian Maritime Zone. Moscow, USSR: Nauka, 1966, 180 p. (in Russian).

Grimley, D. A., L. R. Follmer, and E. D. Mckay. "Magnetic susceptibility and mineral zonation controlled by provenance in loess along the Illinois and central Mississippi River valleys," Quaternary Research, Vol. 49, 1998, pp. 24-36.

Grimm, E. TILIA and TILIAGRAPH. Springfield, IL: Illinois State Museum 1991.

Grinenko, V. S., V. A. Kameletdinov, Yu. L. Slastenov, and O. I. Shcherbakov. "Geological structure of Greater Yakutia," in: Regional Geology of Yakutia. Yakutsk, Russia: Yakutian State University, 1995, pp. 3-20 (in Russian).

Gusev, A. I. "Stratigraphy of Quaternary deposits of the Coastal plain," in: Materialy soveshchaniya po izucheniyu chetvertichnogo perioda (Materials of a Conference on the Study of the Quaternary Period),Vol. III, 1961, pp. 119-127 (in Russian).

Hoops, E. Heavy Mineral Distribution of East Siberian River Sediments. Unpublished Ph.D. thesis, University of Potsdam, 2000 (in German).

Isaeva, L. L. "Late Pleistocene glaciation of north central Siberia," in: A. A. Velichko, H. Wright, and K. W. Barnosky, eds., Late Quaternary Environments of the Soviet Union. Minneapolis, MN: University of Minnesota, 1984, pp. 21-30.

Ivanov, O. A. "Stratigraphy and correlation of Neogene and Quaternary deposits in subarctic plains of East Yakutia," in: Problems of the Study of the Quaternary Period. Moscow, USSR: Nauka Press, 1972, pp. 202-211 (in Russian).

Jouzel, J., L. Merlivat, and C. Lorius. "Deuterium excess in an East Antarctic ice core suggests higher relative humidity at the oceanic surface during the last glacial maximum," Nature, Vol. 299, 1982, pp. 688-691.

Kassens, H., H. A. Bauch, I. A. Dmitrenko, H. Eicken, H.-W. Hubberten, M. Melles, J. Thiede, and L. A. Timokhov, eds. Land-Ocean System in the Siberian Arctic-Dynamics and History. Berlin, Germany: Springer, 1999, 711 p.

Kind, N. V. Geokhronologia pozdnego antropogena po izotopnym dannym (Geochronology of the Late Anthropogene by Isotope Data). Moscow, USSR: Nauka, 1974, $200 \mathrm{p}$.

Kolpakov, V. V. “Eolian deposits in Quaternary of Yakutia," Byulleten' komissii po izucheniyu Chetvertichnogo perioda, Vol. 52, 1983, pp. 123-131. 
Krbetschek, M. R., G. Gonser, and G. Schwamborn. "Luminescence dating results on sediment sequences of the Lena Delta," Polarforschung, Vol. 70, 2002, pp. 83-88.

Kukla, G., F. Heller, X. M. Liu, T. C. Xu, T. S. Liu, and T. S. An. "Pleistocene climates in China dated by magnetic susceptibility," Geology, Vol. 16, 1988, pp. 811-814.

Kunitsky, V. V. Cryolithology in the Lena River Mouth. Yakutsk, USSR: Permafrost Institute, 1989, 162 p. (in Russian).

Kunitsky, V. V., L. Schirrmeister, G. Grosse, and F. Kienast. "Snow patches in nival landscapes and their role for the Ice Complex formation in the Laptev Sea lowlands," Polarforschung, Vol. 70, 2002, pp. 53-67.

Lungersgauzen, G. F. "Geological history of the middle Lena and some questions of Quaternary deposits stratigraphy in East Siberia," in: Materialy soveshchaniya po izucheniyu chetvertichnogo perioda (Materials of a Conference on the Study of the Quaternary Period), Vol. III, 1961, pp. 209-217 (in Russian).

Mange, M. A and H. F. W. Maurer. Schwerminerale in Farbe. Stuttgart, Germany: Ferdinand Enke Publishers, 1991, 148 p. (in German).

MacKay, J. R. "Oxygen isotope variations in permafrost, Tuktoyaktuk Peninsula area, Northwest Territories," Papers of the Geological Survey Canada, Vol. 18, 1983, pp. 67-74.

Mangerud, J., V. Astakhov, and J.-I. Svendsen. "The extent of the Barents-Kara ice sheet during the Last Glacial Maximum," Quaternary Science Reviews, Vol. 21, 2002, pp. 111-119.

Mangerud, J., J. T. Svendsen, and V. Astakhov. "Age and extent of the Barents and Kara ice sheet in Northern Russia," Boreas, Vol. 28, 1999, pp. 46-40.

Melnikov, V. P. and V. I., Spesivtsev. Cryogenic formations in the Earth's lithosphere. Novosibirsk, Russia: Nauka, 2000, 343 p.

Meyer, H., A. Dereviagin, C. Siegert, and H.-W. Hubberten. "Paleoclimate studies on Bykovsky Peninsula, North Siberia. Hydrogen and oxygen isotopes in ground ice," Polarforschung, Vol. 70, 2002, pp. 37-52.

Meyer, H., L. Schönicke, U. Wand, H.-W. Hubberten, and H. Friedrichsen. "Isotope studies of hydrogen and oxygen in ground ice-Experiences with the equilibration technique," Isotopes in Environmental and Health Studies, Vol. 36, 2000, pp. 133-149.

Michel, F. A. Isotope Investigations of Permafrost Water in Northern Canada. Unpubl. Ph.D. thesis, Department. of Earth Sciences, University of Waterloo, Canada, 1982, $227 \mathrm{p}$.

Mikulenko, K. I. "Questions of the geology of the arctic region of West Yakutia," in M. N. Grigoriev, V. S. Imaev, and L. P. Imaeva, eds., Geology, Seismicity and Permafrost Processes of the Arctic Region of West Yakutia. Yakutsk, Russia, 1996 (in Russian).

Nadeau, M. J., P. M. Grootes, M. Schleicher, P. Hasselberg, A. Rieck, and M. Bitterling. "Sample throughput and data quality at the Leibniz-Labor AMS facility," Radiocarbon, Vol. 40, 1998, pp. 239-245.

Nadeau, M. J., M. Schleicher, P. M. Grootes, H. Erlenkeuser, A. Gottdang, D. J. W. Mous, J. M. Sarnthein, and H. Willkomm. "The Leibniz-Labor 
facility at the Christian Albrecht University, Kiel, Germany," Nuclear Instruments and Methods in Physics Research, Vol. 123, 1997, pp. 22-30.

Pavlova, E. Yu. and M. V. Dorozhkina. "Geological-geomorphological studies in the western and central part of the Lena Delta," in V. Rachold and M. N. Grigoriev, eds., Russian-German Cooperation SYSTEM LAPTEV SEA 2000: The Expedition Lena Delta 1999. Report on Polar Research, Vol. 354, 2000, pp. 75-90.

Pisaric, M. F. J., G. M. MacDonald, A. A. Velichko, and L. C. Cwynar. "The late glacial and postglacial vegetation history of the northwestern limits of Beringia based on pollen, stomate and tree stump evidence," Quaternary Science Reviews, Vol. 20, Nos. 1-3, 2001, pp. 235-245.

Polyak, L., V. Gataullin, O. Okuneva, and V. Stelle. "New constraints on the limits of the Barents-Kara ice sheet during the Last Glacial Maximum based on borehole stratigraphy from the Pechora Sea," Geology, Vol. 28, 2000, pp. 611-614.

Polyak, L. and V. Mikhailov. "Post-glacial environments of the southeastern Barents Sea: Foraminiferal evidence," in J. T. Andrews, W. E. N. Austin, H. Bergsten, and A. E. Jennings, eds., Late Quaternary Palaeoocenography of the North Atlantic Margin. Geological Society Special Publication, Vol. 111, 1996, pp. 323-337.

Polyak, L. and A. Solheim. "Late- and postglacial environments in the northern Barents Sea west of Franz Josef Land," Polar Research, Vol. 13, 1994, pp. 197-207.

Rachold, V. "The modern and ancient terrestrial and coastal environment of the Laptev Sea region, Siberian Arctic," Polarforschung, Vol. 70, 2002, pp. 1-2.

Rachold, V. and M. N. Grigoriev, eds. "Russian-German Cooperation SYSTEM LAPTEV SEA 2000: The Lena Delta 1998 Expedition," Reports on Polar Research, Vol. 315, 1999, 268 p.

Rachold V. and M. N. Grigoriev, eds. "Russian-German Cooperation SYSTEM LAPTEV SEA 2000: The Expedition Lena Delta 1999," Report on Polar Research, Vol. 354. 2000, 303 p.

Rachold, V. and M. N. Grigoriev, eds. "Russian-German Cooperation SYSTEM LAPTEV SEA 2000: The Lena Delta 2000 Expedition," Reports on Polar Research, Vol. 388, 2001, 135 p.

Sachs, V. N. and S. A. Strelkov. "Mesozoic and Cenozoic of the Soviet Arctic," in G. O. Raasch, ed. Geology of the Arctic. Proceedings of the First International Symposium on Arctic Geology held in Calgary, Alberta, January 11-13, 1960, under the Auspices of the Alberta Society of Petroleum Geologists, Vol. I. Toronto: University of Toronto Press, 1960.

Schirrmeister, L., V. V. Kunitsky, G. Grosse, T. Kuznetsova, S. Kuzmina, and D. Bolshiyanov. "Late Quaternary and recent environmental situation around the Olenyok Channel (western Lena Delta) and on Bykovsky Peninsula," in V. Rachold, and M. N. Grigoriev, eds., Russian-German Cooperation System Laptev Sea 2000: The Lena Delta 2000 Expedition. Reports on Polar Research, Vol. 388, 2001, p. 85-135.

Schirrmeister, L., D. Oezen, and M. A. Geyh. " ${ }^{230} \mathrm{Th} / \mathrm{U}$ dating of frozen peat, Bol'shoy Lyakhovsky Island (North Siberia)," Quaternary Research, Vol. 57, 2002b, pp. 253-258.

Schirrmeister, L., C. Siegert, T. V. Kuznetsova, S. Kuzmina, A. A. Andreev, F. Kienast, H. Meyer, and A. Bobrov. "Paleoenvironmental and paleoclimatic 
records from permafrost deposits in the Arctic region of Northern Siberia," Quaternary International, Vol. 89, 2002b, pp. 97-118.

Schliesser, G. H. "Parameters determing carbon isotope ratios in plants," in B. Frenzel ed., Problems of Stable Isotopes in Tree-Rings, Lake Sediments and Peat Bogs as Climate Evidence for the Holocene. Paleoclimate Research, Vol. 15, 1995, pp. 71-96.

Schwamborn, G., W. Schneider, M. N. Grigoriev, V. Rachold, and M. Antonow. "Sedimentation and environmental history of the Lena Delta," in V. Rachold and M. N. Grigoriev, eds., Russian-German Cooperation System Laptev Sea 2000: The Lena Delta 1998 Expedition. Reports on Polar Research, Vol. 315, 1999, pp. 94-111.

Schwamborn, G., V. Rachold, and M. N. Grigoriev. "Late Quaternary sedimentation history of the Lena Delta," Quaternary International, Vol. 89, 2002, pp. 119-134.

Svendsen, J. I., V. I. Astakhov, D. Yu. Bolshiyanov, I. Demidov, J. A. Dowdswell, V. Gataullin, Ch. Hjort, H.-W. Hubberten, E. Larsen, J. Mangerud, M. Melles, P. Möller, M. Saarnisto, and M. J. Siegert. "Maximum extent of the Eurasian ice sheet in the Barents and Kara Sea region during the Weichselian," Boreas, Vol. 28, 1999, pp. 234-242.

Tomirdiaro, S. V. Loess-glacial formation of East Siberia in the Late Pleistocene and the Holocene. Moscow, USSR: Nauka, 1980, 184 p. (in Russian).

Tomirdiaro, S. V. "Evolution of lowland landscapes in northern Asia during Late Quaternary time," in D. V. Hopkins, J. V. Matthews, Jr., Ch. E. Schweger, and S. B. Young, eds., Paleoecology of Beringia. New York, NY: Academic Press, 1982, pp. 29-37.

Tomirdiaro, S. V. and B. I. Chernen'kiy. Cryogenic-Eolian Deposits of the Eastern Arctic and Sub-Arctic. Moscow, USSR: Nauka, 1987, 200 p. (in Russian).

Vaikmäe, R. "Oxygen isotopes in permafrost and ground ice-A new tool for paleoclimatic investigations," in Isotopes in Nature. Proceedings of 5th Working Meeting, Leipzig, Germany, 1989, p. 543-553.

van Everdingen, R. O., ed. Multi-language Glossary of Permafrost and Related Ground-Ice Terms. Calgary, Canada: International Permafrost Association (IPA), 1998.

Vasil'chuk, Yu. K. Oxygen Isotope Composition of Ground Ice. Application to Paleogeocryological Reconstruction. Moscow, Russia: Moscow State University, 1992, 420 p. (in Russian).

Vasil'chuk, Yu. K. and V. M. Kotlyakov. Principles of Isotope Geochronology and Glaciology. A Comprehensive Textbook. Moscow, Russia: Moscow State University, 2000, 616 pp. (in Russian).

Vereshchagin, V. N. Stratigraphic Glossary USSR - Paleogene, Neogene, Quaternary. Leningrad, USSR: Nedra, 1982, 616 p.

Washburn, A. L., Geocryology-A Survey of Periglacial Processes and Environments. London, UK: Edward Arnold Ltd., 1979, 406 p.

Welker, J. M. T. H. E. Heaton, B. Spiro, and T.V. Callaghan. "Indirect effect of winter climate on the $\delta^{13} \mathrm{C}$ and $\delta \mathrm{D}$ characteristics of annual growth segments in the long-lived, arctic plant Cassiope tetragona: A preliminary analysis," in: B. Frenzel, ed., Problems of Stable Isotopes in Tree-Rings, Lake Sediments and Peat 
Bogs as Climatic Evidence for the Holocene. Paläoklimaforschung 15. Stuttgart/ Jena, Germany and New York, NY: Fischer, 1995, pp. 105-119.

Wolfe, B. B., T. W. D. Edwards, R. Aravena, S. Forman, L. Warner, A. A. Velichko, and G. M. MacDonald, "Holocene paleohydrology and paleoclimate at treeline, north-central Russia, inferred from oxygen isotope records in lake sediment cellulose," Quaternary Research, Vol. 53, 2000, pp. 319-329. 